The final version of this paper appears in Computers in Industry, Vol. 65, pp. 91-107 (2014).

\title{
Ontology-based Similarity for Product Information Retrieval
}

\author{
Suriati Akmal ${ }^{1}$, Li-Hsing Shih $^{2}$, Rafael Batres ${ }^{1 *}$ \\ ${ }^{1}$ Department of Mechanical Engineering \\ Toyohashi University of Technology, \\ Hibarigaoka 1-1, Tempaku-cho, Toyohashi 441-8580 Japan. \\ ${ }^{2}$ Department of Resources Engineering, National Cheng Kung University, \\ No. 1, University Road, Tainan 701, Taiwan, R.O.C \\ *Corresponding author: E-mail: rafaelbatres@ outlook.com, Tel: +81-(0)532-44-6716
}

Abstract. Product development of today is becoming increasingly knowledge intensive.

Specifically, design teams face considerable challenges in making effective use of increasing amounts of information. In order to support product information retrieval and reuse, one approach is to use case-based reasoning (CBR) in which problems are solved "by using or adapting solutions to old problems." In CBR, a case includes both a representation of the problem and a solution to that problem. Case-based reasoning uses similarity measures to identify cases which are more relevant to the problem to be solved. However, most non-numeric similarity measures are based on syntactic grounds, which often fail to produce good matches when confronted with the meaning associated to the words they compare. To overcome this limitation, ontologies can be used to produce similarity measures that are based on semantics. This paper presents an ontology-based approach that can determine the similarity between two classes using feature-based similarity measures that replace features with attributes. The proposed approach is evaluated against other existing similarities. Finally, the effectiveness of the proposed approach is illustrated with a case study on product-service-system design problems.

Keywords: Semantic Similarity; Ontology; Product Information Retrieval; Formal Concept Analysis.

\footnotetext{
${ }^{1}$ on leave from the Universiti Teknikal Malaysia Melaka, 76109 Durian Tunggal, Melaka, Malaysia
} 


\section{1. Introduction}

Due to the complexity of products, product development is becoming increasingly knowledge intensive. Design is also multi-disciplinary in nature requiring a variety of product life-cycle knowledge [1]. Specifically, design teams face a considerable challenge in making effective use of increasing amounts of information that often accumulate and remain in isolated information systems. Also, it is often the case that product designers can reuse past designs rather than designing from scratch [2].

Information retrieval consists of translating and matching a query against a set of information objects. Translation of the query is necessary for converting the user requirements into the language provided by the information retrieval system. The information retrieval system responds to the query using a given algorithm and a similarity measure. Particularly, information retrieval plays an important role in areas such as product family design [3], product embodiment, and detailed design [4]. Shah et al. [5] present a combination framework that consists of software engineering, data engineering and knowledge engineering and design theory.

In order to support product information retrieval and reuse, some authors suggest the use of case-based reasoning (CBR) in which design problems are solved by using or adapting previous design solutions [4], [6].

A CBR system is composed of domain knowledge, a case base, and a search mechanism based on a similarity measure. Domain knowledge refers to knowledge about the features of the different objects or entities that a case is about. A case base contains a set of cases, each of which describes a problem and a solution to the problem. The problem is typically defined in terms of specific features of objects. Finally, a similarity measure quantifies the differences that exist between objects [7]. CBR uses similarity measures to identify cases which are more relevant to the problem to be solved.

Most similarity measures evaluate differences between values of numeric properties such as in the numerical difference between two given diameter values. However, many applications also 
require non-numeric similarities. For example, case-based reasoning systems for the conceptual design of products must be developed to work with a limited knowledge about the product.

Nearly all of non-numeric similarity measures are based on syntactic grounds. For example, the Levenshtein distance [8], [9] can be used to calculate the similarity between two words, in terms of the minimum number of operations that are needed to transform one of the words into the other. However, from the point of view of the meaning of the words that are compared, existing syntactic similarity-measures often result in incorrect matches.

Semantic similarity measures can be used in order to overcome the limitations of syntactic approaches. A semantic similarity is a function that assigns a numeric value to the similarity between two classes of objects based on the meaning associated to each of the objects [10]. For a review of semantic similarity metrics, the reader is referred to the paper of Cross and $\mathrm{Hu}$ [11].

Recently, the use of ontologies for evaluating similarity has been reported in the literature [12], [13]. Ontologies are formal models that use mathematical logic to disambiguate and define classes of things [14]. Specifically, ontologies describe a shared and common understanding of a domain in terms of classes, possible relations between things, and axioms that constrain the meaning of classes and relations [15]. A class represents a set of things that share the same attributes. A relation is used to represent a relationship among two or more things. Examples of relations are less than, connected to, and part of. Class taxonomies are defined by means of the subclass relation. A class is a subclass of another class if every member of the subclass is also a member of the super class. Axioms are typically represented as logic constructions that formally define a given class or relation.

Combined with automated reasoning applications, ontologies can be used for several purposes such as knowledge extraction and information retrieval. Unfortunately, ontologies are typically created in an ad-hoc manner, which may influence the accuracy of the similarity calculations.

Formal concept analysis (FCA) is a data processing method that can be used to design ontologies [16] [17]. FCA is based on a set of objects and a set of attributes. In this paper, we use FCA along 
with a theoretical framework for developing product and process ontologies.

Most semantic similarities are defined in terms of the number of edges between the classes that they compare (edge-counting similarity measures). Other semantic similarities are defined in terms of features but use synsets for the comparison between words rather than classes.

The underlying thesis in this paper is that if a class represents a set of things that share the same attributes (such as a class in an ontology), we can state that a class is equivalent to another class if both classes have exactly the same attributes. This implies that the more common attributes that are shared by two classes the more similar they are. In this paper, we show how an ontology-based approach can determine the similarity between two classes using feature-based similarity measures that replace features with attributes.

The paper is organized as follows. Section 2 describes the theoretical framework used in this paper. Section 3 provides details on the ontology development. Section 4 describes the proposed ontology-based similarity measures. Sections 5 and 6 describe the evaluation of the semantic measures proposed in this paper. In section 7, the effectiveness of the proposed approach is illustrated with a case study on product-service-system design problems. Section 8 discusses some related work and section 9 presents conclusions and suggestions.

\section{Theoretical framework for product representation}

Theoretical frameworks for product representation refer to the world view with which product information models or ontologies can be developed in order to represent a product. In this paper, the theoretical framework for representing a product is based on the ISO 15926 standard which specifies an upper ontology for long-term data integration, access and exchange [18]. It was developed in ISO TC184/SC4-Industrial Data by the EPISTLE consortium (1993-2003) and designed to support the evolution of data through time. The upper ontology was developed as a conceptual data model for the representation of technical information of process plants including oil and gas production facili- 
1 ties but it was designed to be generic enough for any engineering domain [19].

In this theoretical framework, the device is represented in terms of its physical aspects as well as in terms of its relation to some process (activity in ISO 15926). These aspects are illustrated in the models of Fig. 1 and Fig. 2.

A device is represented as a physical object that is defined in terms of a distribution of matter, energy, or both. The device is also described in terms of its parts. This is possible through a mereological relation that refers to the relationship that a part has in regards to the whole of an object. Mereological relations are reflexive, antisymmetric, and transitive.

Physical objects exist in reference to a specific place. The location relation (relative location in ISO 15926) is a kind of mereological relation that is used to locate objects in a particular place.

A stream is another kind of physical object that is applied to material or energy moving along a path, where the path is the basis of identity and may be constrained. For example, the material moving along a pipe is an instance of stream.

The function of a product can be defined as an intended process associated to the device. For example, the function associated to a sofa is represented as the process of seating in which the sofa is involved along with a person that sits on it. Similarly, the function of an electric fan is to generate cool air. In this case, the description of the device includes information about the cooling process. The cooling process is in turn composed of other processes such as conversion of electricity into rotary movement, convection, diffusion and heat transfer. Therefore information about the process or processes associated to the device is an indispensable element to complete the description of the product.

Different objects can participate in a process. Participating physical objects include those objects that are transformed by the process, those objects that are produced by the process, those objects that are not affected by the process (the device itself, other tools, or instruments), as well as agents (such as a person or a control system) that participate or execute the process. 
2 its mereology.

3 line.

As in the description of the device, a process is also described in terms of its relative location and

\section{Ontology construction}

There are a number of methodologies to develop ontologies including Uschold and King's method [25], Grüninger and Fox's method [26], Noy and McGuiness's method [27], the METHONTOLOGY framework [28], the Cyc methodology, KACTUS, SENSUS, and the On-To-Knowledge Methodology [29].

According to Stevens et al. [30], the general stages for ontology development are: identification of purpose and scope, knowledge acquisition, conceptualization, integration, encoding, documentation, and evaluation. We follow these general steps, but we use FCA (see Appendix 1) and the theoretical framework described in Section 2 to guide the knowledge acquisition and conceptualization stages.

Candidate classes that may or may not appear in the final ontology are identified, and the object column of a FCA context table is populated with these classes.

Subsequently, information sources such as scientific papers, technical reports, and Internet resources are consulted to define each class in natural language. When several definitions are found preference is given to those that explicitly describe participating objects, objects transformed by the process (inputs), objects produced by the process (outputs) and/or subactivities. When contradictions among several definitions of a given class occur experts can be consulted to disambiguate.

Formal attributes are identified from the natural-language definitions using the following guide-

A device (a physical object) is characterized by:

1. The process in which the device participates.

2. The composition of the device (its parts).

In turn, a given process or the process in which the device participates is characterized by the 
1

following:

- The object that is transformed by the process (the input of the process)

- The object that is produced by the process (the output of the process).

- The tool that is present in any instance of the process.

- The composition of the process.

After adding the formal attributes, the context table is completed and a lattice is generated. Lattices in this paper were generated by means of the Grail algorithm [24], which is implemented in the software Concept Explorer. Finally, the lattice is used to create the ontology. The naming of each class is done based on object or attributes labels from the nodes in the lattice.

Integration is carried out by means of aligning the resulting ontology with an upper ontology that defines domain-independent classes such as physical objects, activities, mereological and topological relations. For example, a class refrigerator is defined as a subclass of physical_object, which is a class of the ISO 15926 upper ontology.

\section{Ontology-based semantic similarities}

In a given ontology, a class is equivalent to another class if both classes have exactly the same attributes $^{2}$. Therefore, the more common attributes that are shared by two classes the more similar they are.

The proposed approach consists of combining feature-based similarities with an ontology obtained with the procedure described in Section 3 and using formal attributes from the FCA as features. The feature-based similarities investigated in this paper are: the Tversky index [21], the Dice's coefficient [22], the Jaccard's coefficient [31], the Overlap coefficient [23], the all-confidence similarity [23], and the Cosine similarity.

\footnotetext{
2 The attributes of a class also include those attributes inherited from its parent classes.
} 
For example, Tversky index becomes:

$2 \quad \operatorname{sim}_{\text {Tversky }}\left(C_{1}, C_{2}\right)=\frac{\left|A_{1} \cap A_{2}\right|}{\left|A_{1} \cap A_{2}\right|+\alpha\left|A_{1} \backslash A_{2}\right|+\beta\left|A_{2} \backslash A_{1}\right|}$

$9 \quad \operatorname{sim}_{\text {vanDerWeken } 1}\left(C_{1}, C_{2}\right)=\frac{\left|A_{1}^{\prime} \cap A_{2}^{\prime}\right|}{\min \left(\left|A_{1}^{\prime}\right|,\left|A_{2}^{\prime}\right|\right)}$

$10 \operatorname{sim}_{\text {vanDerWeken } 2}\left(C_{1}, C_{2}\right)=\frac{\left|A_{1}^{\prime} \cap A_{2}^{\prime}\right|}{\max \left(\left|A_{1}^{\prime}\right|,\left|A_{2}^{\prime}\right|\right)}$ and $C_{2}$. sets instead of fuzzy sets: complements of sets $A_{1}$ and $A_{2}$. similarities: similarity measures.

where $\alpha$ and $\beta$ are parameters calculated according to Rodriguez and Egenhoffer [32], $A_{1}$ and $A_{2}$ are the sets of attributes of classes $C_{1}$ and $C_{2},\left|A_{1} \cap A_{2}\right|$ is the total number of formal attributes shared by $C_{1}$ and $C_{2},\left|A_{1}\right|$ and $\left|A_{2}\right|$ represent the number of formal attributes of $C_{1}$

We also use the similarity equations given by van der Weken et al. [33] but using formal attribute

where $A_{1}$ and $A_{2}$ are the sets of attributes of classes $C_{1}$ and $C_{2}$; and $A_{1}^{\prime}$ and $A_{2}^{\prime}$ are the

No restriction exists for one of the classes to be a subclass or a superclass of the other. In other words, the classes to be compared can happen anywhere in the ontology.

In addition, we also investigate a composite similarity obtained by combining semantic

$$
\operatorname{sim}_{\text {Comvosite }}\left(C_{1}, C_{2}\right)=w_{1} \operatorname{sim}_{1}+w_{2} \operatorname{sim}_{2}
$$

where $w_{1}$ and $w_{2}$ are weights and $\operatorname{sim}_{1}$ and $\operatorname{sim}_{2}$ represent two different semantic

In order to compare against edge-counting similarity measures, calculations are also carried out using both Wu-Palmer's [20] and Lin's [10] similarity measures.

\section{Experimental evaluation of the proposed approach using human judgment}


$20 \quad s_{j}=\frac{\bar{q}_{j}-q^{\min }}{q^{\max }-q^{\min }}$ errors.

$d_{i}=\sum_{j}\left|q_{i j}-\mu_{i j}\right|$

This experiment focuses on the domain of electric home appliances for the evaluation of different semantic similarities. The evaluation is carried out by measuring the degree of correlation between the calculated similarity scores and scores obtained by human judgments. For this purpose, a questionnaire was administered to 30 respondents. The questionnaire asked each respondent to rank the likeness between 'electric kettle' and each of 17 home electric appliances. Respondents then rated the similarity of the pairs on a 1-17 scale, with lower numbers indicating higher similarity.

The comparison was carried out by calculating the correlation coefficient and the sum of squared

The level of inconsistency of each questionnaire was calculated with the following formula.

where $q_{i j}$ is the value of the score that participant $i$ submitted for pair $j$ and $\mu_{i j}$ is the mean of the scores of all the users except that of user $i$ for pair $j$. Using this formula, questionnaires with values of $d_{i}$ above two standard deviations from the mean $\bar{d}_{i}$ were excluded from the analysis.

The average standard deviations of the scores across respondents were also evaluated to identify inconsistencies. Since one of the questionnaires had a standard deviation lower than average, it was not taken into account. With this last change, the sample size was reduced from 30 to 27.

Finally, individual pair scores with one standard deviation below or above the pair mean $\bar{q}_{j}$ were eliminated, which accounted for $4 \%$ of the total data.

Subsequently, the average scores were normalized using the following transformation:

where $s_{j}$ represents the similarity of pair $j, q^{\max }=17$ and $q^{\min }=1$. Values of $s_{j}$ are shown in the first column of Table 1.

\subsection{Ontology development}


In this section, we describe the development of an electric home appliance ontology, which is based on the method described in section 3. The list of potential classes was extracted from product categories in Amazon.com and the attribute information was obtained using the characterization explained in Section 3, using expert consultations and brainstorming. In the development of the ontology, we focused on the process or processes in which the given appliance participates or is involved. Therefore, formal attributes include a reference to the process or a description of the process in terms of the objects that are transformed by the process and the objects that are produced by the process. For example, the formal attribute identification of an electric kettle starts by the analyzing its main process associated to it, which is a process that produces hot water. Heating is a part of that process. In order to produce hot water, the electric kettle consumes electricity that is converted into thermal energy that is used to heat water. Therefore, the formal attributes of an electric kettle become 'heats', 'produces hot water', 'heats water', and 'consumes electricity'. With formal-attribute information obtained this way, a context table was created (Fig. 3). Subsequently, Concept Explorer [24] was used to generate the concept lattice shown in Fig. 4. After analyzing and correcting the lattice, the final lattice and formal-attribute information were used to develop an ontology using the Protégé ontology editor [34]. Subsequently, the resulting ontology was saved in OWL format [35].

Strictly speaking, formal attribute information must be in the form of axioms as in the following example.

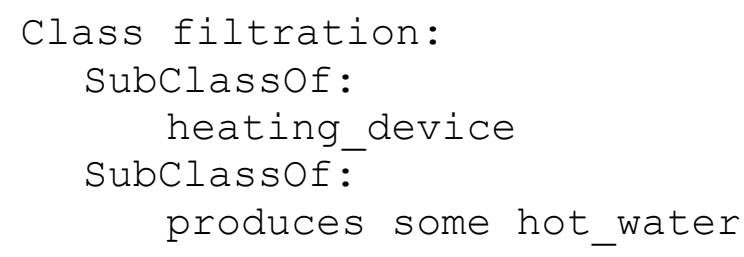

However, for simplicity in the similarity calculation, formal attributes were added as OWL properties. For example, the formal attribute for "produces hot water" is declared as follows:

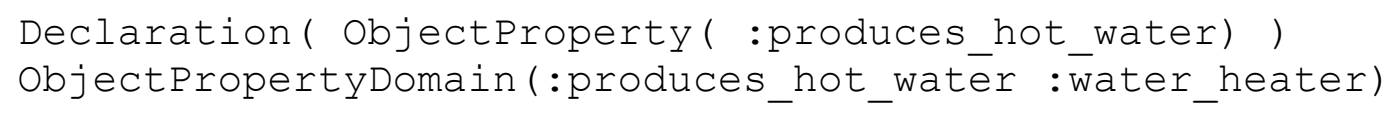


This resulted in an OWL file with 33 classes, 39 properties, and 5 levels in the class hierarchy.

\subsection{Similarity calculation}

A program was developed in Java using the ontology library Jena [36]. The program reads the ontology and the names of the two classes to be compared. Firstly, it extracts the formal attribute information of each class in the ontology. Then, the program proceeds to calculate the cardinalities for each set of attributes, the minimum and maximum values, and the number of overlapped attributes. Attributes of a class include those inherited from all its parent classes. Similarity calculations are then carried out using the feature-based similarities as explained in Section 4. Then the Wu-Palmer's and Lin's similarities are calculated by edge counting, using the taxonomy structure of the ontology.

\subsection{Experiment results}

Table 1 summarizes the calculation results of the investigated similarities rating between 17 class comparisons.

We introduced 'device' as subclass of physical_object (defined in ISO 15926) and made 'home electric appliance' a subclass of 'device'. From Table 1, it can be seen that the best performing similarity is the Overlap coefficient ( sim $_{\text {Overlap}}$ ) with $R=0.795$ followed by the Wu-Palmer similarity with $R=0.782$, the Cosine similarity ( sim $_{\text {Cosine }}$ ) with $R=0.781$, and Dice's coefficient with ( $\operatorname{sim}_{\text {Dice }}$ ) with $R=0.777$.

After considering every possible combination of feature-based similarities for the composite similarity equation of Equation (4), the best two combinations were:

$$
\operatorname{sim}_{\text {Cosine+Iaccard }}\left(C_{1}, C_{2}\right)=1.887 \text { sim }_{\text {Cosine }}-0.887 \text { sim }_{\text {Iaccard }}
$$

with a correlation of $R=0.817$ and

$$
\operatorname{sim}_{\text {Dice+Jaccard }}\left(C_{1}, C_{2}\right)=1.966 \text { sim }_{\text {Dice }}-0.966 \text { sim }_{\text {Jaccard }}
$$


with a correlation of $R=0.816$.

The weights $w_{1}$ and $w_{2}$ were obtained by numeric optimization so as to minimize the residual sum of squares between the composite similarity and $s_{j}$ of Equation (6).

\subsection{Analysis of the results}

To eliminate biases in the analysis of the results, we removed those pairs that produced squared errors greater than two times the standard deviation. The pairs (electric kettle, television set) and (electric kettle, electric oven) produced the biggest squared error. After removing both pairs, the correlation value of the Overlap coefficient increased to $R=0.947$. Again, $\operatorname{sim}_{\text {Cosine }} \quad(R=0.922)$ and $\operatorname{sim}_{\text {Dice }} \quad(R=0.919)$ were second and third in performance, respectively. For the combined similarities, $\operatorname{sim}_{\text {Cosine }+ \text { Jaccard }} \quad$ increased to $R=0.950$ and $\operatorname{sim}_{\text {Dice }+ \text { Jaccard }} \quad$ increased to $R=0.947$.

A hierarchical cluster analysis was conducted in order to compare relatively homogeneous groups of results. The cluster analysis was equally applied to both the human assessment results and the results obtained with the Overlap coefficient. Clustering was carried out using Ward's minimum variance algorithm.

A comparison of the clusters indicates that most of the object pairs that belong to one cluster with the Overlap coefficient also belong to a cluster in the results of human judgment. As shown in Fig. 5, only (electric kettle, television set), (electric kettle, air conditioner), and (electric kettle, bread machine) were grouped into another cluster. This is probably due to missing attributes in the FCA context table. Alternatively, another possible reason is that these three pairs were particularly difficult to judge during the answering of the questionnaire.

\section{Experimental evaluation of the proposed approach using Web search}

This experiment uses the Web to evaluate the different similarity measures. In order to increase the accuracy of the Web-based evaluation, a more technical domain was selected. For this reason, we 
1 chose machining processes as the technical domain. Moreover, the evaluation was carried out with

2 the search engines provided by Google's Scholar and Elsevier's Scirus.

Despite the existence of a vast variety of machining processes, in order to obtain a compact on-

tology, the scope of this experiment was limited to mechanical material removing processes. In order to develop the ontology, several common textbooks [37], [38] [39], [40], [41] and an Internet source [42] were consulted. The potential classes are listed in the first column of Table 3.

During the construction of the ontology, in order to determine the formal attributes for the context table, all the material removing processes were characterized according to the process characterization explained in Section 3.

Fig. 6 shows the context table with the classes of material removing processes. The resulting concept lattice is presented in Fig. 7. The similarity measures were the same as in the experiment of Section 5. The above mentioned Java program was used in all the calculations.

This time, the resulting similarity scores were compared against the Web-based similarity denoted by equation (9).

$v\left(t_{i}, t_{j}\right)=1-d\left(t_{i}, t_{j}\right)$

where $v\left(t_{i}, t_{j}\right)$ is the Web-similarity of terms $t_{i}, t_{j}$, and $d\left(t_{i}, t_{j}\right)$ represents the distance function proposed by Cilibrasi and Vitanyi [43] also known as the normalized Google distance or NGD. The distance function of Cilibrasi and Vitanyi is described by equation (10).

$d\left(t_{i}, t_{j}\right)=\frac{\max \left(\log f\left(t_{i}\right), \log f\left(t_{j}\right)\right)-\log f\left(t_{i}, t_{j}\right)}{\log M-\min \left(\log f\left(t_{i}\right), \log f\left(t_{j}\right)\right)}$

where $f\left(t_{i}\right), f\left(t_{j}\right)$ and $f\left(t_{\underline{i}}, t_{j}\right)$ give the number of hits for the terms $t_{i}, t_{j}$ and $\left(t_{\underline{i}}, t_{j}\right)$ respectively. $M$ corresponds to the number of indexed documents in a given Web search engine. The number of indexed documents of Scirus which is reported on its Web page is $4.6 \times 10^{8}$ as of May 21, 2012. A value of $\mathrm{M}=5.8 \times 10^{8}$ for Google Scholar was obtained from an earlier estimate [44] and by assuming a growth rate of $2.7 \%$ based on the world-wide average annual increase of academic papers [45].

In order to restrict the Web search to the domain of study, keywords in both search engines were 
1 formulated with the inclusion of the term "machining" and search was carried out using double 2 quotes.

3 For example, for the similarity between counterboring and spot facing, search with Scholar for "machining" "counterboring" results in $f$ (counterboring)=1019 hits; search for "machining" "spot facing" produces $f$ (spot facing)=620 hits; and search for "machining" "counterboring" "spot facing" results in $f$ (counterboring, spotfacing) $=56$ hits. Substituting these values in Equation (10) gives $d($ counterboring, spotfacing $)=0.2146$. Using Equation $(9)$ we obtain $v($ counterboring, spot facing $)=$ 0.7854

Calculations were carried out for pairwise similarities between all the pairs of processes, resulting in 45 comparisons. Table 2 summarizes the results of the calculations.

The best single similarity measure was the van der Weken similarity ( $\operatorname{sim}_{\text {vanDerWeken } 2) \text { with }}$ correlation coefficients of $R=0.828$, and $R=0.916$, for Scirus and Scholar respectively. Then, the Jaccard's coefficient $\left(\operatorname{sim}_{\text {Jaccard }}\right)$ came up second.

\section{Case Study}

In this case study we focus on the effectiveness of the ontology-based semantic similarities in the context of product-service system (PSS) design. A PSS is a mix of both products and services that is often associated to better sustainability. In the design of PSS systems, one common design decision is the selection of the type of service that can be integrated with a given product [6].

A CBR system was developed in Java by extending the open source software FreeCBR. As in any traditional CBR system, each case is defined in terms of a problem and a solution. In this case study, the problem is defined in terms of case features that represent characteristics of a given product. The case features can be numeric or semantic. For numeric features, the index approach proposed by Lin et al. is used [6]. The semantic feature is specified as the class to which the product belongs, that is defined in a product ontology. The similarity for such semantic feature was 
1 calculated using the Overlap coefficient and the formal attributes of each class. A screen dump of the

2 CBR system is shown in Fig. 8.

3 The case similarity in the CBR system is calculated using the equation proposed by Kolodner and

4 Simpson [46]:

$5 \quad S(t, r)=\frac{\sum_{i=1}^{n} w_{i} \times \operatorname{sim}\left(f_{i}^{t}, f_{i}^{r}\right)}{\sum_{i=1}^{n} w_{i}}$

6

where $S(t, r)$ is the global similarity between the target case $t$ and a source case $r ; w_{i}$ is

7 the weight of feature $i ; f_{i}^{t}$ is the value of feature $i$ of target case $t$; and $f_{i}^{r}$ is the value of

8 feature $i$ of a source case $r$.

$9 \operatorname{sim}\left(f_{i}^{\tau}, f_{i}^{r}\right)$ is calculated according to the following criteria, which is based on the Overlap

10 coefficient and a similarity for numerical attributes.

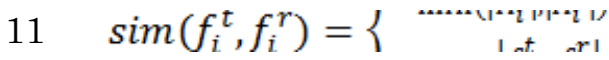

where $A_{i}^{\tau}$ is the set of formal attributes of the class specified in feature $f_{i}^{t} ; A_{i}^{r}$ is the set of formal attributes of the class specified in feature $f_{i}^{r}$; and $f_{i}^{\max }$ and $f_{i}^{\min }$ are the maximum and minimum numeric values of feature $f_{i}$ respectively.

\subsection{Ontology development}

A product ontology was developed based on the procedure described in Section 3 and using the list of products reported in [6]. The resulting concept lattice is shown in Fig. 9. The product ontology extends the upper ontology defined in the ISO 15926 standard [15]. To carry out the alignment, three classes were added as subclasses of physical object: substance, mixture, and device based on [47]. During the preparation of the FCA context table, attributes were selected by investigating the process or processes in which the product participates or is involved. Each process was described 
according to the process characterization explained in Section 3. For example, the objects that are transformed during the operation of a copier are the data input by the user, electricity, and paper and the objects that are produced by the same process are the copied printed paper. Thus, the attributes of the copier become: consumes data, consumes electricity, consumes paper, and produces printed paper.

\subsection{Experiment setup}

The case base was populated with information about 47 successful product services systems. Each case was described in terms of numerical and semantic features. Based on [6], the following numeric features and weights were used: place of usage of the PSS system $\left(w_{1}=0.116\right)$, frequency of usage of the PSS system $\left(w_{2}=0.232\right)$, product fashion cycle $\left(w_{3}=0.0 .042\right)$, product volume $\left(w_{4}=0.036\right)$, product weight $\left(w_{5}=0.034\right)$, product useful life $\left(w_{6}=0.064\right)$, product price $\left(w_{7}=0.082\right)$, subsequent expenditure $\left(w_{8}=0.116\right)$, GDP per capita $\left(w_{9}=0.119\right)$, population density $\left(w_{10}=0.079\right)$, area of territory $\left(w_{11}=0.052\right)$, and temperature range of the territory $\left(w_{12}=0.059\right)$. The allowable values for each numeric feature and their meaning is also explained in [6]. For example, the index used to describe the place of usage of the PSS system is defined for integer values ranging from 1 to 3, where 1 represents indoor, 3 outdoor and 2 both. Among these features, product fashion cycle, volume, weight, useful life, and price are product features. The objective of this experiment was to evaluate the possibility of using a semantic feature as a replacement of some of the product attributes. The semantic feature consisted of the class of product defined in the product ontology.

Initially, two experiments were carried out. The objective of experiment 1 was to provide a reference for comparing the proposed approach. For this purpose, all the queries in experiment 1 consisted of values for all the numerical features without the semantic feature.

In experiment 2, queries were formulated by replacing two product features (product volume and 
1 product weight) by the corresponding class of product from the ontology. The weight for this seman-

2 tic feature was set to $w_{13}=0.07$.

3 The case similarity in both experiments were calculated with equations (11) and (12).

The queries were formulated with the product information from each of the cases stored in the case base. Therefore, 47 problems were defined with the problem data of the 47 cases in the case

6 base, resulting in a total of 94 experiments. The objective was to find the service strategy and then compare the result with the already known service strategy of the corresponding case. For example, problem 1 describes a certain kind of washing machine that was used in PSS that provided a repair service. In this example, it is thus expected that all if not most of the $n$ best matches return repair as the solution. information, the proposed service strategy, and a global similarity value. Then the resulting service strategies were compared against the original service. Table 3 shows the results for both experiments. The best five matches are shown for each problem. From the overall results, it can be observed that there are 9 problems (Nos. 1, 5, 10, 14, 18, 26, 28, 43 and 45) in which the results of experiment 1 are identical with those of experiment 2. For example, the best five service strategies in problem 1 were: refrigerator-repair, computer-repair, water heater-repair, laser printer-repair and LCD monitor-repair, all of which are consistent to the repair service corresponding to the solution of problem 1. $12,19,20,33,34,37,38,40,41$ and 42 produced the same five best matches found in the results of experiment 1 but with a different ranking. For example, in problem 11 both experiments resulted in treadmill-lease, dryer-lease, LCD TV-lease, refrigerator-lease and dish washer-lease. However, while treadmill-lease has the highest rank in experiment 1, it appears second in experiment 2.

In addition, there were 27 results (such as problems $2,3,4,6,7,8$, and 9) that differed in one or two cases. For example, the results for problem 2 include an Internet-based digital calendar which is 
1 false positive. On the other hand, some results of experiment 2 were good matches albeit being

2 missing in experiment 1 . For example, (sofa-lease and platform bed-lease instead of jewelry-rental

3 and handbag rental) in problem 9 are good matches.

Furthermore, the results of experiment 2 for problems 30 (photocopy-service), 31 (scanning-service) and 32 (laminating-service) are better when compared to the results of experiment 1 in which not only the best 5 matches refer to a service that equals that of the case from which the query was formulated (pay per service unit) but also the product is more compatible with that of the suggested service. For example, experiment 2 for problem 30 resulted in laundry-service, printing-service, eyeglass cleaning-service, scanning-service and fax-service. Among these, printing, scanning and fax can be carried out with a copier machine. These results contrast with those obtained with experiment 1 which included cleaning-service, eyeglass cleaning-service and shoes cleaning service.

In order to corroborate the influence of the semantic similarity, an additional experiment was conducted (experiment 3). Experiment 3 excluded the numeric product features of volume and weight as well as the semantic feature. For this evaluation, we counted the cases in the best five results that were common to those in experiment 1 . In other words, the ideal number of common cases is 5. These results are summarized in Table 4. The presence of the semantic similarity measure in experiment 2 resulted in an average of 4.32 common cases, while its absence in experiment 3 resulted in an average of 3.79. This means that in the absence of data for product volume and weight, the use of the semantic feature shows an improvement of almost $14 \%$ compared to not using it. From this, it can be concluded that ontology-based semantic similarities have the ability to emulate (at least to some extent) the numeric product features.

\section{Related work}

Several efforts are reported on the use of ontologies in product design. One interesting exam- 
1 ple is the work of Patil et al [48] who describe an ontology that is based on definitions from the

2 NIST's Core Product Model. They describe a methodology for building artifact ontologies which is 3 based on the identification of subclasses of artifact, feature, assembly, and other classes. In the ontology development process, each artifact is characterized in terms of its form, function, and behavior (the implementation of the function).

Annamalai et al. [49] define a general framework for product-service systems that is facilitated by means of an ontology. The terminologies and semantics are based on 8 top-level classes that cover product life cycle and the supporting elements such as stakeholder involvement. The ontology is developed using findings from literature review and the opinion of domain experts.

In the area of product customization, Tseng et al. [50] present a CBR system to support conceptual product design. In their work, a numeric similarity measure is combined with part-whole information that has a tree representation. Another similar work is that of Cobb and Agogino [51] who developed a CBR system for designing Micro-Electro-Mechanical Systems (MEMS). They discuss the results of a case-retrieval experiment in which MEMS are described in terms of functional and structural features. These features are numeric, which suggest that case retrieval is carried out by means of a numeric similarity.

In an attempt to generate new product ideas, Wu et al. [52] propose a CBR system in which a product is represented as a numeric vector consisting of 87 elements. Each element represents a product attribute. The product attributes are organized into five dimensions: interface modality, task, physical feature, environment, and users. Some of the attributes in the interface modality resemble the use of the participation relation defined in ISO 15926 such as specifying the parts of the body involved in [the use of] a given product. The task dimension represents the tasks to be performed by the user through the use of the product. Attributes in this dimension are equivalent to specific processes associated to a product. The physical dimension is for attributes such as product sizes. Environment includes attributes such as indoor or outdoor places. Finally, attributes in the user dimension 
1 characterize the user in terms of gender, age, etc. Every attribute in the product vector requires a

2 value that represents the relevancy to that attribute.

3 Lin et al. [6] propose the use of CBR to support the design of product service systems (PSS). Specifically, their CBR selects service strategies for a given product. A case is described in terms of 12 features which are grouped into three categories, namely, user behavior, product, and environmental environment. User behavior is specified in terms of place of usage, and frequency of usage.

7 The product is specified in terms of features describing its fashion cycle, volume, weight, useful life, 8 price, and subsequent expenditure. External environment is defined in terms of GDP per capita, population density, area of territory, and temperature range. Each feature is quantified using integer values. The case similarity is obtained by using a weighted summation of all the feature similarities. The weights are determined by means of the Analytic Hierarchy Process (AHP).

In the area of Web services, Bramantoro et al. [13] propose a similarity measure that quantifies the semantic distance between classes in an ontology of the products that are delivered by the services. Their work is motivated by limitations of other approaches in which only certain superclass-subclass links were taken into account. Their approach was based on the path length, number of downward edges counted between two classes, and the number of common closest ancestors. It is interesting to note that despite the fact that some semantic measures already existed they were apparently unknown in that domain.

\section{Conclusions}

This paper presented ontology-based semantic similarity measures that determine the degree of likeness between two classes. The main distinguishing aspect of the proposed approach is the use of ontologies obtained with FCA coupled with feature-based similarities. Results of the numeric experiments showed that in all cases, the proposed semantic measures performed better than the similarities of Wu Palmer and Lin. 
In the electric appliance experiment, after removing the least performing pairs (electric kettle,

2 television set) and (electric kettle, electric oven), the correlation saw an increase of approximately

$325 \%$. The reason might be that both television set and electric oven were characterized by processes

which are unfamiliar to the common user. For example, toaster was characterized as a device that uses infrared radiation. In this case, infrared radiation was considered as a part of heating, which is directly related to toasting bread. Similarly, TV set was defined as a device that receives television 7 signals.

When other devices were characterized in terms of processes and participating objects that were more familiar to the common user, the calculated similarities were close to the human judgments. However, albeit important to the designers, from a user point of view, subprocesses that are not directly perceived by the users (i.e. the mechanism with which a product achieves its given function) are probably not taken into account. This could be a limitation of the questionnaire approach for evaluating the similarities. ilarity measures. In the CBR case study, the combination of the ontology and the semantic similarity proved useful when some details such as weight and volume are not available. Therefore, the designer can be relieved by needing less data to define a given design problem, which is particularly important during the conceptual stage of the design.

Nevertheless, in a few instances the proposed approach resulted in mismatches. This could be due to the lack of attributes in the FCA context table. For example, the addition of attributes that emphasize the difference between software and hardware products could reduce the number of false positives for problem 2 .

A key element in the proposed approach is the use of FCA. From an information modeling point of view, the use of formal concept analysis is useful but the development of the context table has a large degree of freedom. Specifically, the selection of attributes in the context table of the FCA 
[1] H. A. ElMaraghy, W. A. ElMaraghy (Eds.), Advances in design, Springer, 2006, p. 31.

[2] M. L. Maher, "Process models for design synthesis," AI Magazine Volume 11(4), 1990.

[3] S. Szykman, J. Racz, C. Bochenek and R. D. Sriram, "Web-based system for design artifact modeling," Design Studies, vol. 21, no. 2, pp. 145-165, 2000.

[4] S. K. Ong, A. Y. Nee and Q. L. Xu, "Design reuse for embodiment and detail design," in Design Reuse in Product Development Modeling, World Scientific Pub. Co Inc., 2009, pp. 237-247. 
[5] J. J. Shah, D. K. Jeon, S. D. Urban, P. Bliznakov and M. Rogers, "Database infrastructure for supporting engineering design histories," Computer-Aided Design, vol. 28, no. 5, pp. 347-360, 1996.

[6] K. Lin, L. Shih, S. Lu, Y. Lin, "Strategy selection for product service systems using case-based reasoning, " African Journal of Business Management, Vol. 4(6), pp. 987-994, 2010.

[7] M. M. Richter, "Similarity," in Case-Based reasoning for signals and imaging, Springer Verlag, 2007, pp. 25-90.

[8] P. Cunningham, "A taxonomy similarity mechanisms for case-based reasoning," UCD-CSI, 2008.

[9] A. Maedche and S. Staab, "Comparing ontologies - similarity measures and a comparison study," Institute AIFB, University of Karlsruhe, Karlsruhe, Germany, 2001.

[10] D. Lin, "An information-theoretic definition of similarity," Proc. 15th Int. Conf. on Machine Learning, Madison, Wisconsin, 1998.

[11] V. Cross and X. Hu, "Using semantic similarity in ontology alignment," in Sixth International Workshop on Ontology Matching, 2011.

[12] V. Olehschuk and A. Pedersen, "Ontology based semantic similarity for documents," in 14th International Workshop on Database and Expert System Application, Prague, 2003.

[13] A. Bramantoro, S. Krishnaswamy and M. Indrawan, "A semantic distance measure for matching web services," in LCNS 3807, WISE 2005 Workshops, New York, 2005.

[14] J. S. Madin, "Advancing ecological research with ontologies," Trends in Ecology \& Evolution, Vol 23(3), pp. 159-168, 2008.

[15] R. Batres, M. West, D. Leal, D. Price, K. Masaki, Y. Shimada, T. Fuchino and Y. Naka, "An Upper Ontology based on ISO 15926," Computers And Chemical Engineering, vol. 31, p. 519-534, 2007.

[16] H. Haav, "A Semi-automatic method to ontology design by using FCA," Proc. 4th Int. Conf. on Concept Lattices and Their Applications, pp. 13-24, 2004.

[17] R. Batres, Y. Shimada and T. Fuchino, "A semantic approach for incident database Development," in IChemE Symposium Series No. 155, 477-484, 2010.

[18] ISO-TC-184, "ISO-TC-184/SC4, SO 10303, "Industrial automation systems and integration - product data representation and exchange- Part 11: description methods: The EXPRESS language reference manual," ISO TC 184/SC4, 1994.

[19] D. Leal, "ISO 15926 "Life cycle data for process plant": an Overview," Oil \& Gas Science and Technology, 60, vol. 4, pp. 629-637, 2005.

[20] Z. Wu and M. Palmer, "Verbs semantics and lexical selection," in 32nd Annual Meeting of the Associations for Computational Lingustics, New Mexico, 1994.

[21] A. Tversky, "Features of similarity," Psychological Review, vol. 84, No. 4, pp. 327-352, 1977.

[22] L. R. Dice, "Measures of the amount of ecologic association between species," Ecology, vol. 26, no. 3, pp. 297-302, 1945.

[23] J. Han and M. Kamber, Data mining: concepts and techniques, 2nd ed. Morgan Kaufmann Pub., an imprint of Elsevier, 2006.

[24] S. Yevtushenko, "Concept explorer, open source java software.," 2009. [Online]. Available: http://sourceforge.net/projects/conexp, Release 1.3.

[25] M. Uschold and M. King, "Towards a methodology for building ontologies," in Workshop on Basic Ontological Issues in Knowledge Sharing, 1995.

[26] M. Grueninger and M. S. Fox, "Methodology for the design and evaluation of ontologies," in Workshop on Basic Ontological Issues in Knowledge Sharing, 1995.

[27] N. F. Noy and D. McGuinness, "Ontology development 101: a guide to creating your first ontology," Stanford Knowledge Systems Laboratory Technical Report KSL-01-05, Standford USA, 2001.

[28] M. Fernandez-Lopez, A. Gomez-Perez and N. Juristo, "Methontology: from ontological art towards ontological engineering," AAAI Technical Report SS-97-06, 1997.

[29] A. Gomez-Perez, "Evaluation of taxanomic knowledge in ontologies and knowledge bases," in Twelfth Workshop on Knowledge Acquisition, Modelling, and Management (KAW '99), Alberta, Canada, 1999.

[30] R. Stevens, C. A. Coble and S. Bechhofer, "Ontology-based knowledge representation for bioinformatics," Briefings in Bioinformatics, Vol. 1, No. 4, pp. 398-414, 2000.

[31] J. Han , M. Kamber and J. Pei, "Getting to know your data," in Data mining: concepts and techniques, United States of America, Morgan Kaufmann, 2013, p. 71. 
[32] M. A. Rodríguez and M. Egenhofer, "Determining semantic similarity among entity classes from different ontologies," IEEE Transactions on Knowledge and Data Engineering, vol. 15, pp. 442-456, 2003.

[33] D. van der Weken, M. Nachtegael and E. E. Kerre, "Using similarity measures and homegeneity for the comparison of images," Image and Vision Computing, pp. 695-702, 2004.

[34] Stanford Center for Biomedical Informatics Research., [Online]. Available: <http://protege.stanford.edu>.

[35] Web-Ontology working group, "OWL web ontology language (2nd Ed.)," <http://www.w3.org>, 2004.

[36] Jena, "HP Labs Semantic Web Toolkit.," [Online]. Available: <http://jena.sourceforge.net/>.

[37] R. E. Schafrik, "Unit Manufacturing and Assembly Process, in: J. Lee," in Modern Manufacturing, Mechanical Engineering Handbook, CRC Press LLC, 1999, pp. 13-8 - 13-34.

[38] S. Kalpakjian and S. R. Schmid, Manufacturing Engineering and Technology, Sixth Edition, Prentice-Hall, 2010.

[39] B. S. Nagendra Parashar and R. K. Mittal, Elements of manufacturing processes, Prentice-Hall of India Private Limited, 2007.

[40] E. P. Degarmo, J. T. Black and R. A. Kohser, Materials and Processes in Manufacturing (10th ed.), Wiley, 2010.

[41] B. Handley, D. M. Marshall and C. Coon, Principles of Engineering, Delmar, 2012.

[42] M. C. Finishing, "Blasting Technical Information," [Online]. Available: http://mcfinishing.com/resources/blastingtech.pdf. [Accessed 2012].

[43] R. Cilibrasi and P. Vitanyi, "The Google Similarity Distance," IEEE Transactions On Knowledge and Data Engineering, vol. 19 , no. 3, pp. 370-383, 2007.

[44] Giustini, D., "How big is Google Scholar? 500 million Documents?," 2006. [Online]. Available: http://blogs.ubc.ca/googlescholar/2006/04/how-big-is-google-scholar-500-million-documents/. [Accessed 25 May 2012].

[45] National Science Board, "Science and Engineering Indicators 2010," National Science Foundation NSB 10-01, Arlington, VA, 2010.

[46] J. Kolodner, R. L. Simpson, "Case-based reasoning in Lin, K. H., Shih, L. H., Lu, S. S., and Lin, Y. T., 2010, Strategy selection for product service systems using case-based reasoning, " African Journal of Business Management Vol. 4(6), 1993.

[47] A. Pease, "Suggested Upper Merged Ontology (SUMO)," [Online]. Available: <http://www.ontologyportal.org/>. [Accessed 2010 December 2010].

[48] L. Patil, D. Dutta and R. D. Sriram, "Ontology formalization of product semantics for product semantics for product life cycle management," NISTIR 7274, November 2005.

[49] G. Annamalai, R. Hussain, M. Cakkol and R. Roy, "An ontology for product-service systems," Cranfield University, Cranfield, Bedfordshire, UK, 2011.

[50] H.-E. Tseng, C.-C. Chang and S.-H. Chang, "Applying case-based reasoning for product configuration in mass customization environments," Expert Systems with Applications, pp. 913-925, 2005.

[51] C. L. Cobb and A. M. Agogino, "Case-based reasoning for the design of micro-electro-mechanical systems," in ASME 2006 International Design Engineering Technical Conferences \& Computers and information in Engineering Conference, Pennsylvania, USA, 2006.

[52] M. C. Wu, Y. F. Lo and S. H. Hsu, "A case-based reasoning apporach to generating new product ideas," Int. J. Adv. Manuf Technology, vol. 30, pp. 166-173, 2006. 


\section{Appendix 1. Formal Concept Analysis}

Formal Concept Analysis (FCA) can be used to design ontologies from a list of potential classes and their respective attributes. FCA is an analysis technique for information processing based on applied lattice and order theory that can be used to generate taxonomies. In FCA, information is organized in terms of a set of formal objects $O$, a set of formal attrib-

utes $A$, and a set of binary relations $Y \subseteq O \times A$ containing all pairs $\langle o, a\rangle \in Y$ such that the object $o \in O$ has the attribute $a \in A$. For our purposes, the formal objects represent candidate classes for an ontology.

Information about these three sets is typically summarized by a context table such as the one shown in Fig. 3. In a context table, the objects are listed in the first column and the attributes in the first row of the table.

A formal concept is defined as the pair $\left\langle O_{i}, A_{i}\right\rangle$ such that:

1. $O_{i} \subseteq O, A_{i} \subseteq A$.

2. Every object in $O_{i}$ has every attribute in $A_{i}$. Conversely, $A_{i}$ is the set of attributes shared by all the objects in $O_{i}$.

3. For every object $p \in O$ that is not in $O_{i}$, there is an attribute in $A_{i}$ that $p$ does not have.

4. For every attribute in $A$ that is not in $A_{i}$, there is an object in $O_{i}$ that does not have that attribute.

Formal concepts can be partially ordered into a lattice, such that a concept subsumes another concept. Fig. 4 shows the lattice obtained with the data of Fig. 3. Several lattice-construction algorithms are available some of which have been successfully implemented in several applications. 
Figure 1. Composition of device presentation .

Figure 2. Composition of device and its relation to processes.

Figure 3. Context table for an ontology of home electric appliances.

Figure 4. Concept lattice obtained with the context table of Figure 3.

Figure 5. Results of the cluster analysis.

Figure 6. The context table of material removal process.

Figure 7. The concept lattice of material removal process.

Figure 8. Screen dump of the user interface of the semantic CBR system.

Figure 9. The concept lattice of products.

Table 1. Comparison between similarity measures.

Table 2. The results for experiments of material removal process.

Table 3. The results for experiments of product-service system.

Table 4. Comparison of identical cases. 
Figure 1

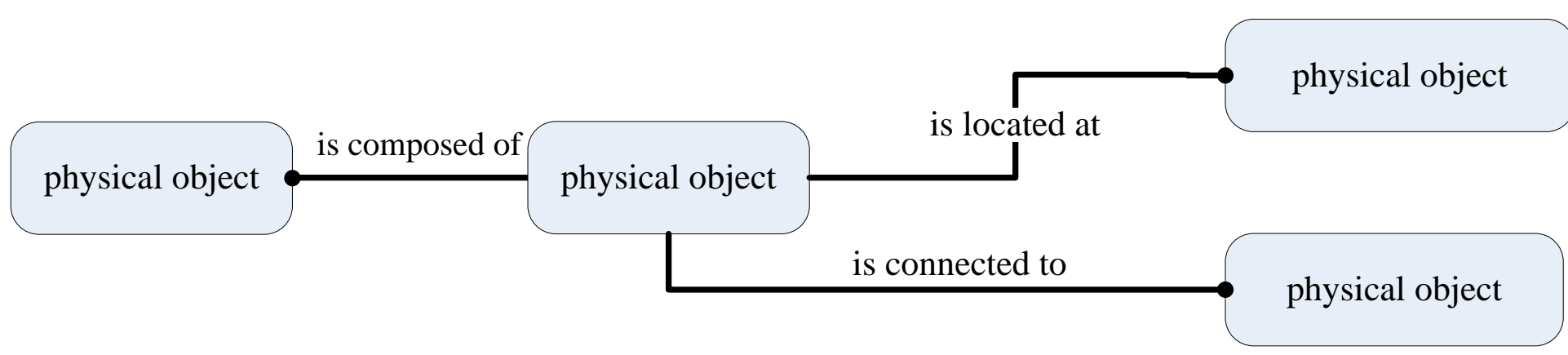




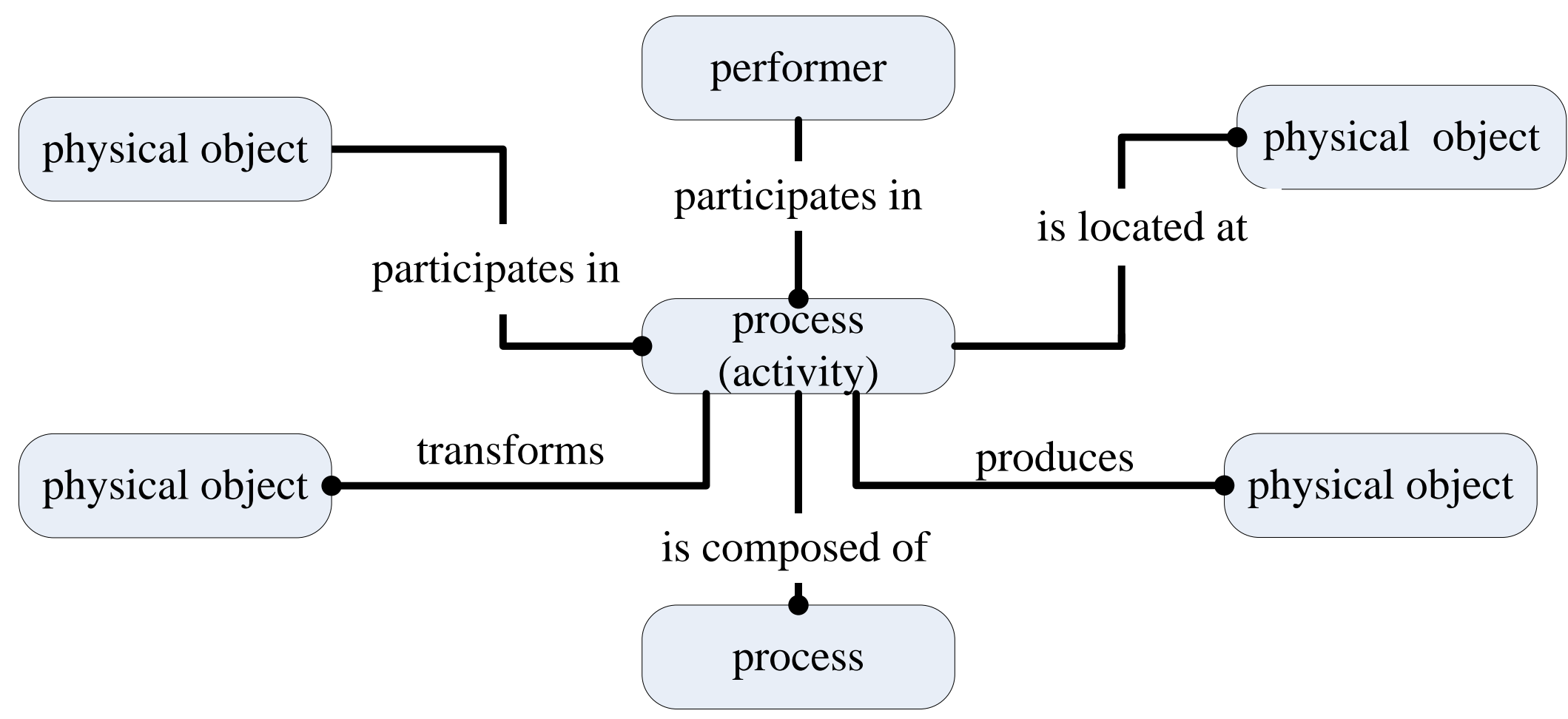


Figure 3

\begin{tabular}{|c|c|c|c|c|c|c|c|c|c|c|c|c|c|c|c|c|c|c|c|c|c|c|c|c|c|c|c|c|c|c|c|c|c|}
\hline & $\begin{array}{c} \\
\\
3 \\
0 \\
0 \\
0 \\
0 \\
0 \\
0 \\
0 \\
0 \\
0 \\
0 \\
0 \\
0 \\
0 \\
0 \\
\end{array}$ & 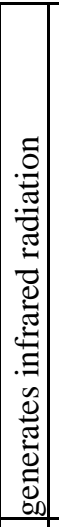 & 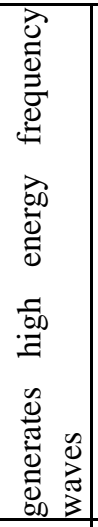 & 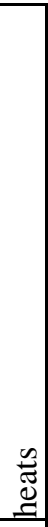 & 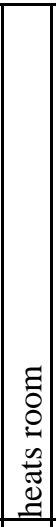 & 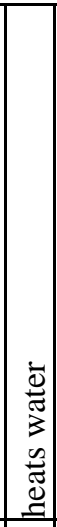 & $\begin{array}{l}2 \\
0 \\
0 \\
0 \\
0 \\
0 \\
0 \\
\end{array}$ & 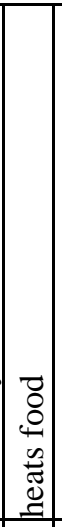 & 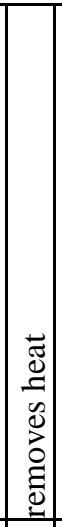 & 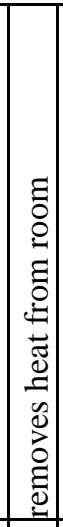 & 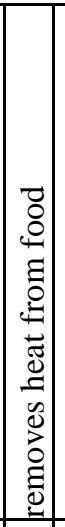 & 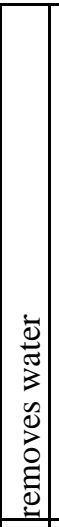 & 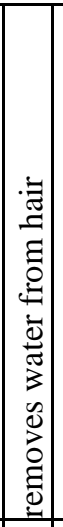 & $\mid \begin{array}{c}0 \\
0 \\
0 \\
0 \\
0 \\
\Xi \\
0 \\
0 \\
0 \\
\overline{0} \\
\tilde{\Xi} \\
3 \\
0 \\
0 \\
0 \\
0 \\
0 \\
0 \\
0\end{array}$ & 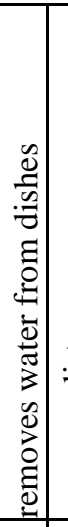 & \begin{tabular}{|c|} 
\\
\\
\\
$:$ \\
$:$ \\
0 \\
0 \\
0 \\
0 \\
0 \\
0 \\
0 \\
0 \\
0 \\
\end{tabular} & 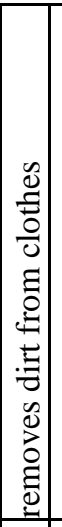 & 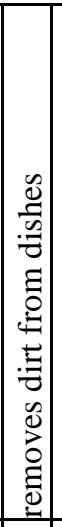 & 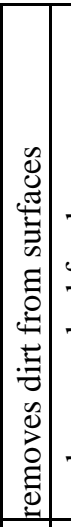 & \begin{tabular}{l|l} 
& \\
7 \\
8 \\
0 \\
0 \\
0 \\
0 \\
0 \\
8 \\
0 \\
0 \\
0 \\
0 \\
0 \\
0 \\
0 \\
0 \\
0
\end{tabular} & . & 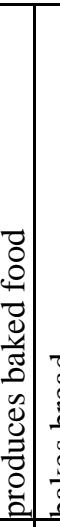 & 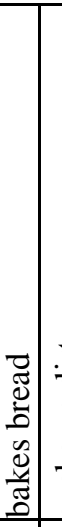 & 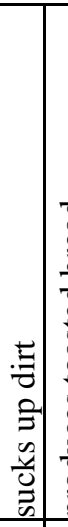 & 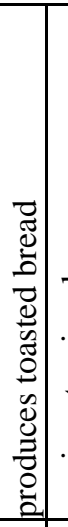 & 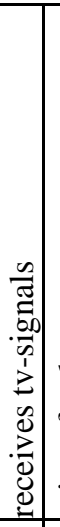 & 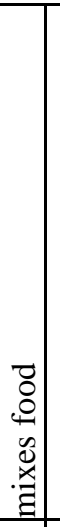 & \begin{tabular}{|c|} 
\\
\\
\\
0 \\
0 \\
0 \\
0 \\
0 \\
0 \\
0 \\
0 \\
\end{tabular} & 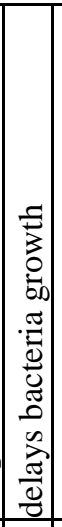 & 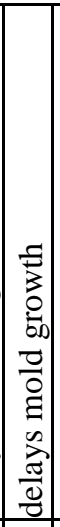 & 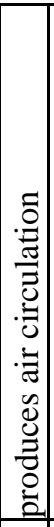 & \begin{tabular}{|c|} 
\\
\\
\\
0 \\
0 \\
0 \\
0 \\
0 \\
0 \\
$\tilde{z}$ \\
0 \\
0 \\
\end{tabular} & 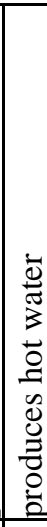 \\
\hline home electric appliances & $\mathrm{x}$ & & & & & & & & & & & & & & & & & & & & & & & & & & & & & & & & \\
\hline room electric heater & $\mathrm{x}$ & & & $\mathrm{x}$ & $\mathrm{x}$ & & & & & & & & & & & & & & & & & & & & & & & & & & & & \\
\hline hair dryer & $\mathrm{x}$ & & & $\mathrm{x}$ & & & & & & & & $\mathrm{x}$ & $\mathrm{x}$ & & & & & & & & & & & & & & & & & & & & \\
\hline electric blanket & $\mathrm{x}$ & & & $\mathrm{x}$ & & & $\mathrm{x}$ & & & & & & & & & & & & & & & & & & & & & & & & & & \\
\hline washing machine & $\mathrm{x}$ & & & & & & & & & & & $\mathrm{x}$ & & $\mathrm{x}$ & & $\mathrm{x}$ & $\mathrm{x}$ & & & & & & & & & & & & & & & & \\
\hline electric clothes dryer & $\mathrm{x}$ & & & $\mathrm{x}$ & & & & & & & & $\mathrm{x}$ & & $\mathrm{x}$ & & & & & & & & & & & & & & & & & & & \\
\hline refrigerator & $\mathrm{x}$ & & & & & & & & $\mathrm{x}$ & & $\mathrm{x}$ & & & & & & & & & & & & & & & & & & $\mathrm{x}$ & $\mathrm{x}$ & & & \\
\hline room air-conditioner & $\mathrm{x}$ & & & $\mathrm{x}$ & $\mathrm{x}$ & & & & $\mathrm{x}$ & $\mathrm{x}$ & & & & & & & & & & & & & & & & & & & & & $\mathrm{x}$ & & \\
\hline electric dish washer & $\mathrm{x}$ & & & & & & & & & & & $\mathrm{x}$ & & & $\mathrm{x}$ & $\mathrm{x}$ & & $\mathrm{x}$ & & & & & & & & & & & & & & & \\
\hline microwave oven & $\mathrm{x}$ & & $\mathrm{x}$ & $\mathrm{x}$ & & & & $\mathrm{x}$ & & & & & & & & & & & & $\mathrm{x}$ & & & & & & & & & & & & $\mathrm{x}$ & \\
\hline toaster & $\mathrm{x}$ & $\mathrm{x}$ & & $\mathrm{x}$ & & & & $\mathrm{x}$ & & & & & & & & & & & & & & & & & $\mathrm{x}$ & & & & & & & $\mathrm{x}$ & \\
\hline electric kettle & $\mathrm{x}$ & & & $\mathrm{x}$ & & $\mathrm{x}$ & & & & & & & & & & & & & & & & & & & & & & & & & & & $\mathrm{x}$ \\
\hline television set & $\mathrm{x}$ & & & & & & & & & & & & & & & & & & & & & & & & & $\mathrm{x}$ & & & & & & & \\
\hline conventional electric fan & $\mathrm{x}$ & & & & & & & & $\mathrm{x}$ & $\mathrm{x}$ & & & & & & & & & & & & & & & & & & & & & $\mathrm{x}$ & & \\
\hline blender & $\mathrm{x}$ & & & & & & & & & & & & & & & & & & & & & & & & & & $\mathrm{x}$ & $\mathrm{x}$ & & & & $\mathrm{x}$ & \\
\hline bread machine & $\mathrm{x}$ & & & $\mathrm{x}$ & & & & $\mathrm{x}$ & & & & & & & & & & & & & $\mathrm{x}$ & & $\mathrm{x}$ & & & & & & & & & $\mathrm{x}$ & \\
\hline electric oven & $\mathrm{x}$ & $\mathrm{x}$ & & $\mathrm{x}$ & & & & $\mathrm{X}$ & & & & & & & & & & & & \begin{tabular}{l|l}
$\mathrm{x}$ & $\mathrm{z}$ \\
\end{tabular} & \begin{tabular}{l|l}
$\mathbf{x}$ & \multicolumn{1}{c}{$(x)$} \\
\end{tabular} & $\mathrm{x}$ & & & & & & & & & & $\mathrm{X}$ & \\
\hline water heater & $\mathrm{x}$ & & & $\mathrm{x}$ & & $\mathrm{x}$ & & & & & & & & & & & & & & & & & & & & & & & & & & & $\mathrm{x}$ \\
\hline vacuum cleaner & $\mathrm{x}$ & & & & & & & & & & & & & & & $\mathrm{x}$ & & & $\mathrm{x}$ & & & & & $\mathrm{x}$ & & & & & & & & & \\
\hline
\end{tabular}


Figure 4

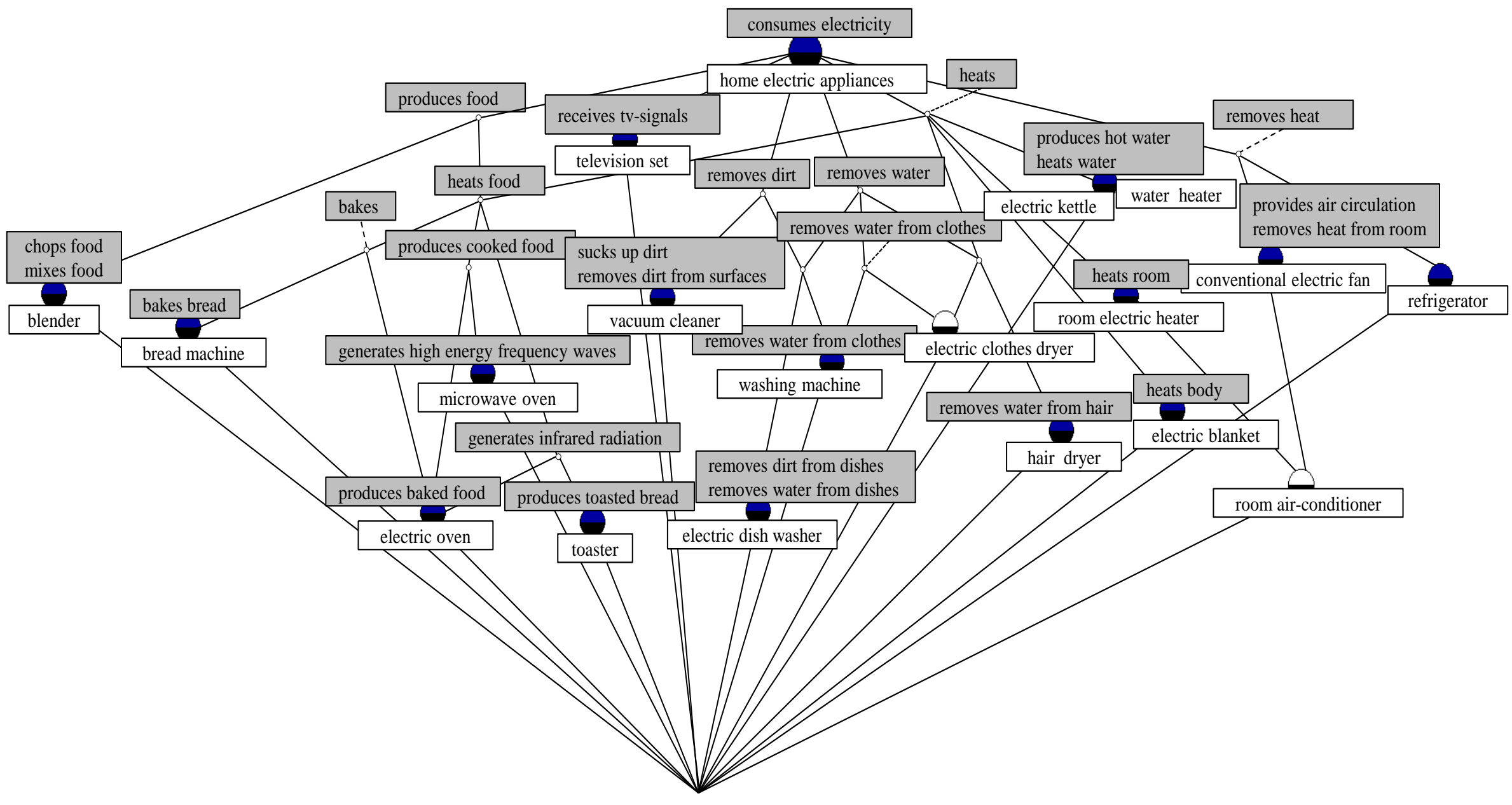




\section{Figure 5}
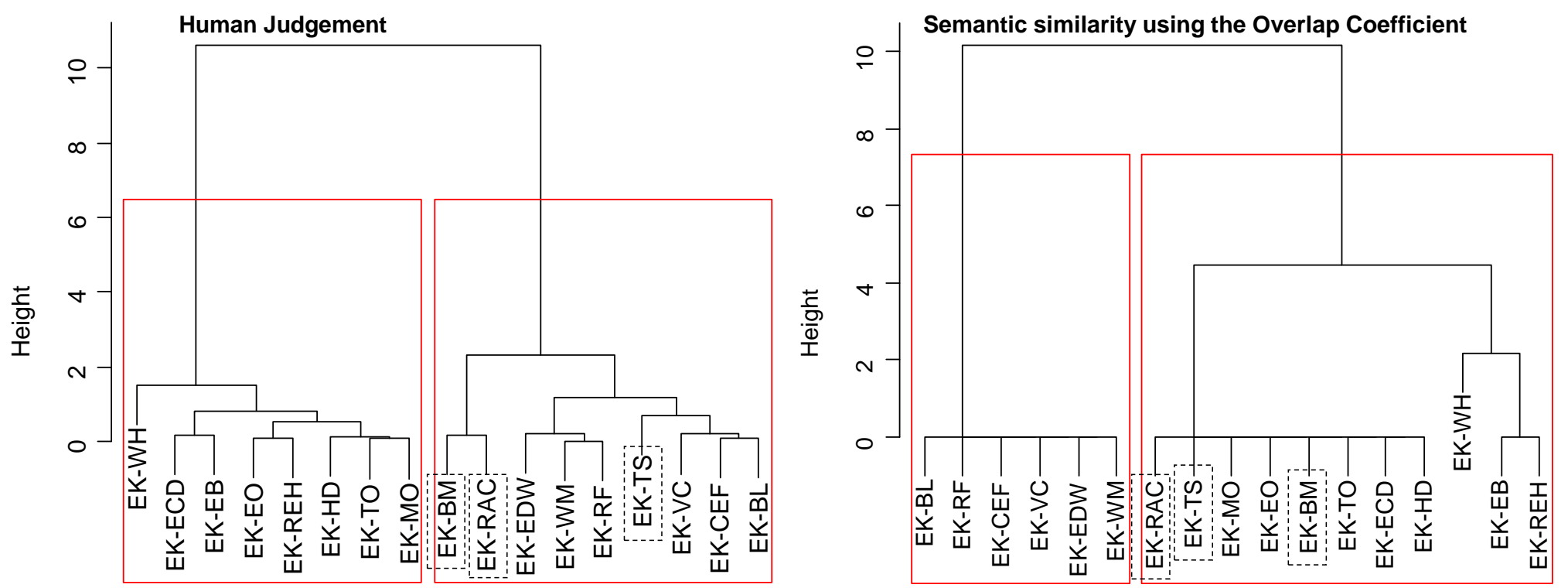


\begin{tabular}{|c|c|c|c|c|c|c|c|c|c|c|c|c|c|c|c|c|c|c|}
\hline & 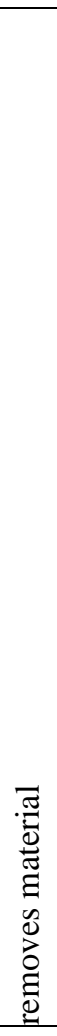 & 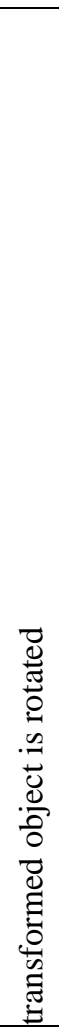 & 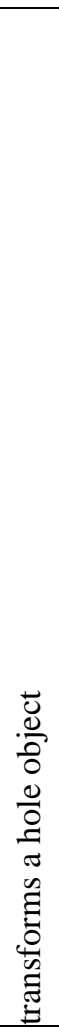 & 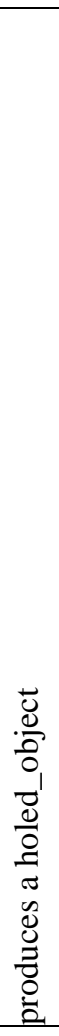 & 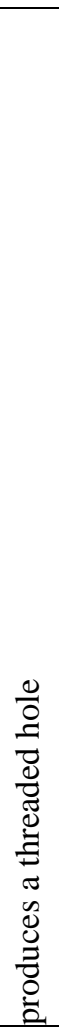 & 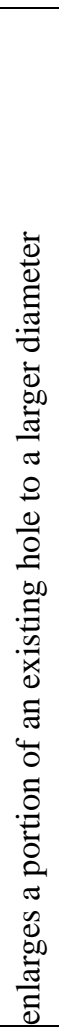 & 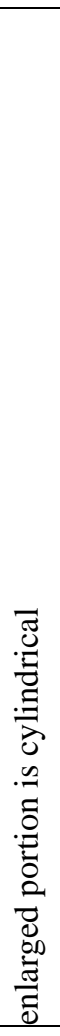 & 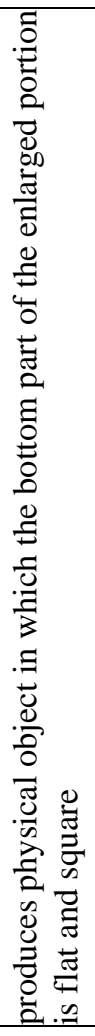 & 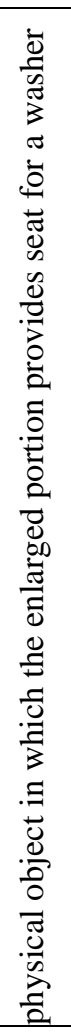 & 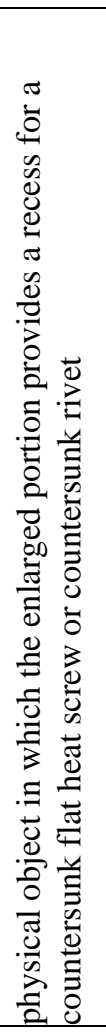 & 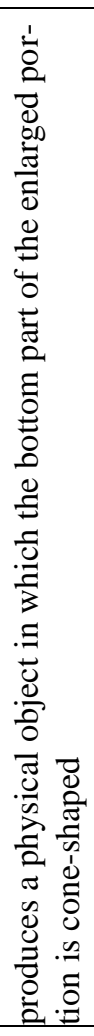 & 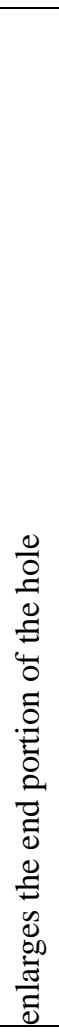 & 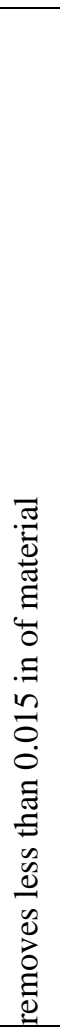 & 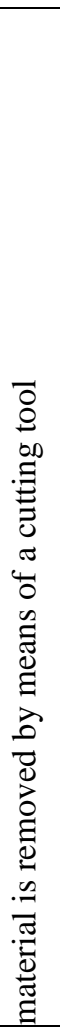 & 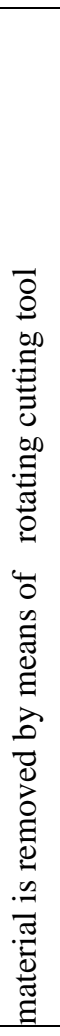 & 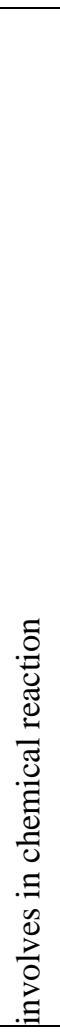 & 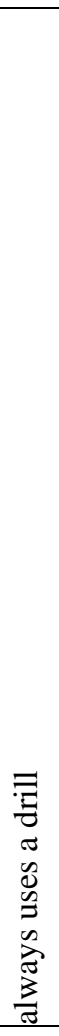 & 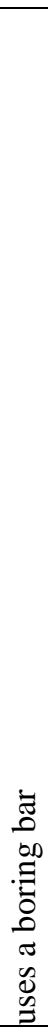 \\
\hline drilling & $\mathrm{x}$ & & & $\mathrm{x}$ & & & & & & & & & & $\mathrm{x}$ & & & $\mathrm{x}$ & \\
\hline boring & $\mathrm{x}$ & & $\mathrm{x}$ & $\mathrm{x}$ & & $\mathrm{x}$ & $\mathrm{x}$ & & & & & & & $\mathrm{x}$ & & & & $\mathrm{x}$ \\
\hline reaming & $\mathrm{x}$ & & $\mathrm{x}$ & $\mathrm{x}$ & & $\mathrm{x}$ & $\mathrm{x}$ & & & & & & $\mathrm{x}$ & $\mathrm{x}$ & & & & \\
\hline tapping & $\mathrm{x}$ & & $\mathrm{x}$ & $\mathrm{x}$ & $\mathrm{x}$ & $\mathrm{x}$ & $\mathrm{x}$ & & & & & & & $\mathrm{x}$ & & & & \\
\hline counterboring & $\mathrm{x}$ & & $\mathrm{x}$ & $\mathrm{x}$ & & $\mathrm{x}$ & $\mathrm{x}$ & $\mathrm{x}$ & & & & $\mathrm{x}$ & & $\mathrm{x}$ & & & & \\
\hline spot facing & $\mathrm{x}$ & & $\mathrm{x}$ & $\mathrm{x}$ & & $\mathrm{x}$ & & $\mathrm{x}$ & $\mathrm{x}$ & & & $\mathrm{x}$ & & $\mathrm{x}$ & & & & \\
\hline coutersinking & $\mathrm{x}$ & & $\mathrm{x}$ & $\mathrm{x}$ & & $\mathrm{x}$ & & & & $\mathrm{x}$ & $\mathrm{x}$ & $\mathrm{x}$ & & $\mathrm{x}$ & & & & \\
\hline turning & $\mathrm{x}$ & $\mathrm{x}$ & & & & & & & & & & & & $\mathrm{x}$ & & & & \\
\hline miiling & $\mathrm{x}$ & & & & & & & & & & & & & $\mathrm{x}$ & $\mathrm{x}$ & & & \\
\hline chemical machining & $\mathrm{x}$ & & & & & & & & & & & & & & & $\mathrm{x}$ & & \\
\hline
\end{tabular}


Figure 7

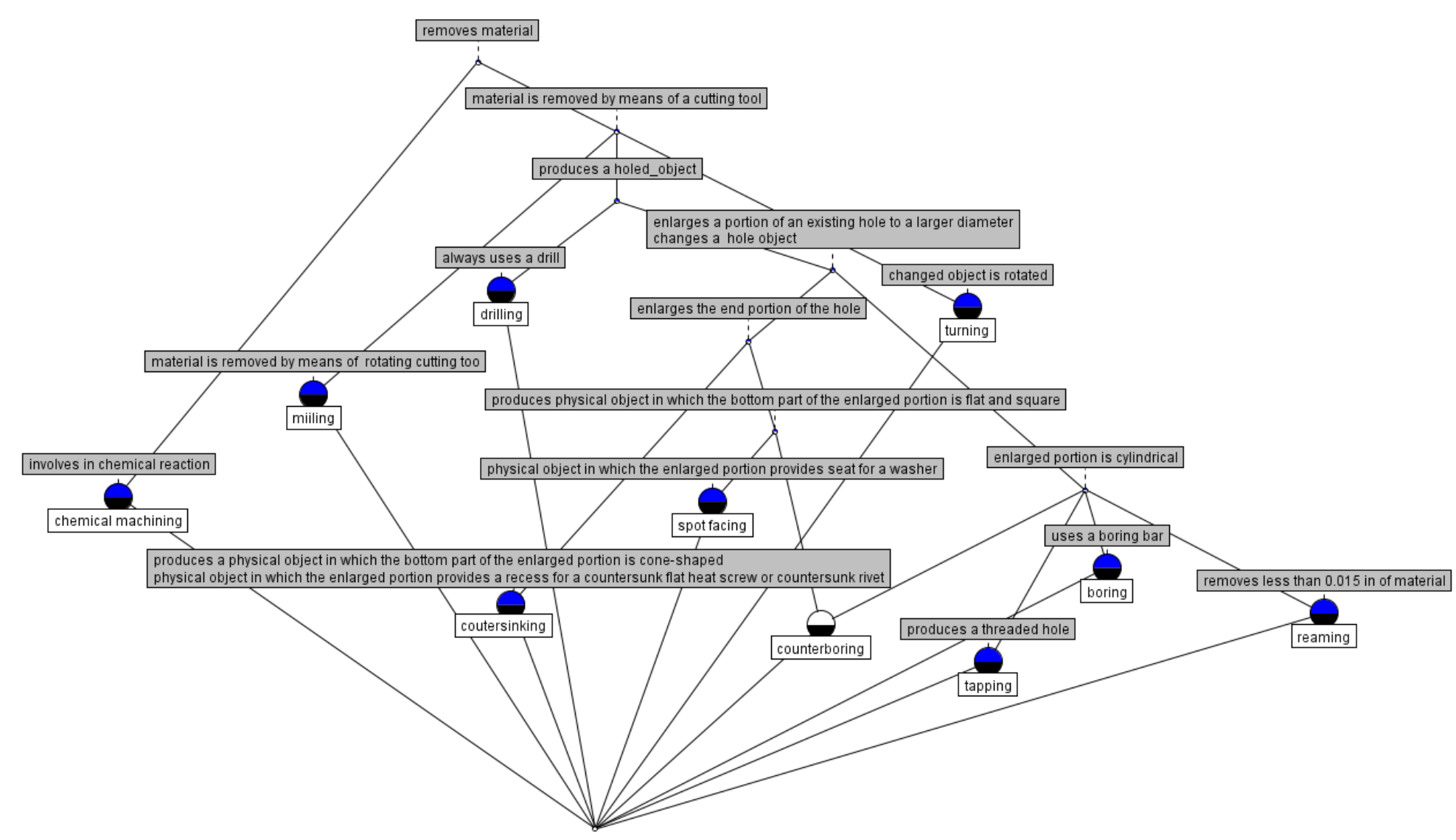


Figure 8

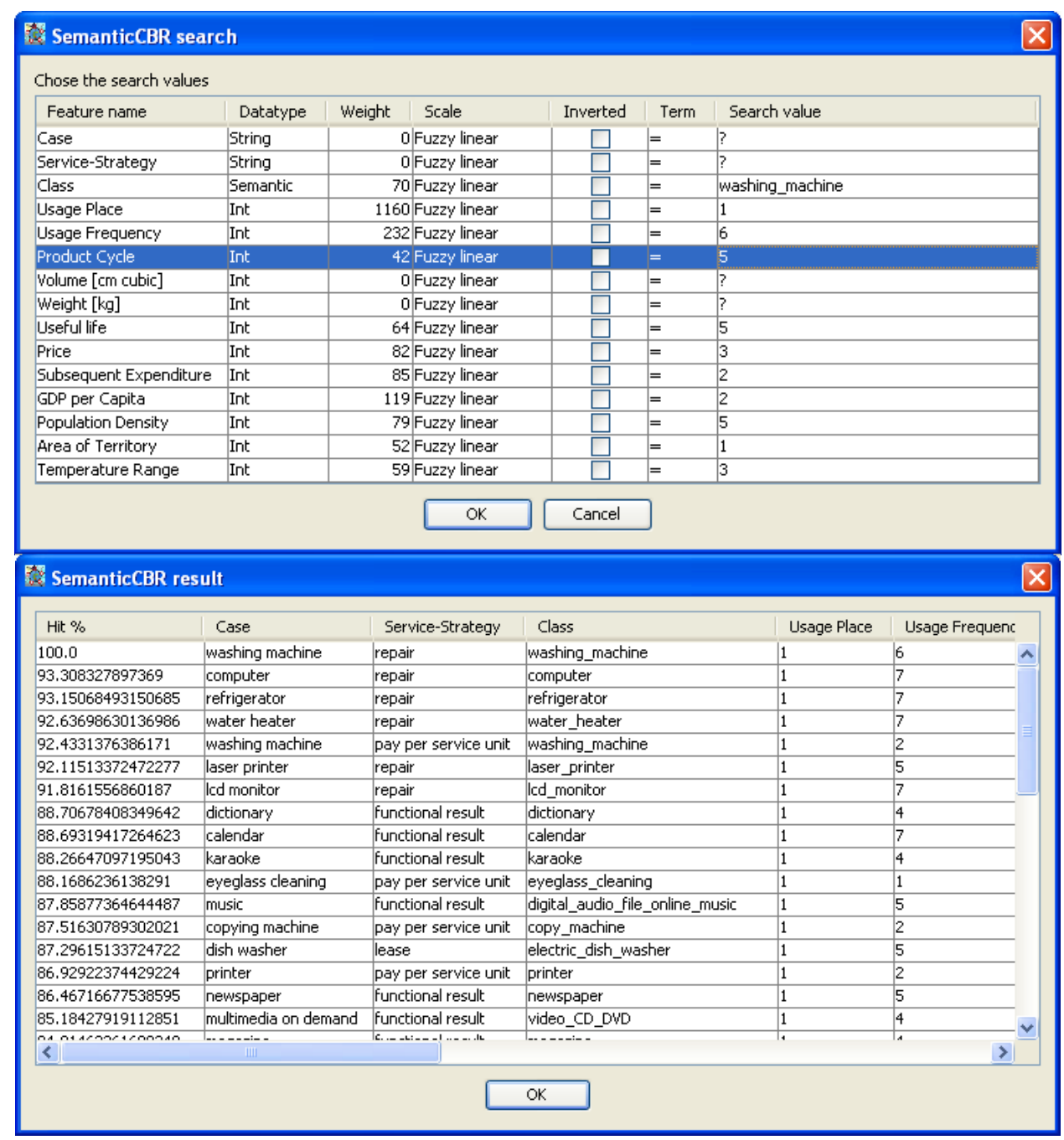


Figure 9

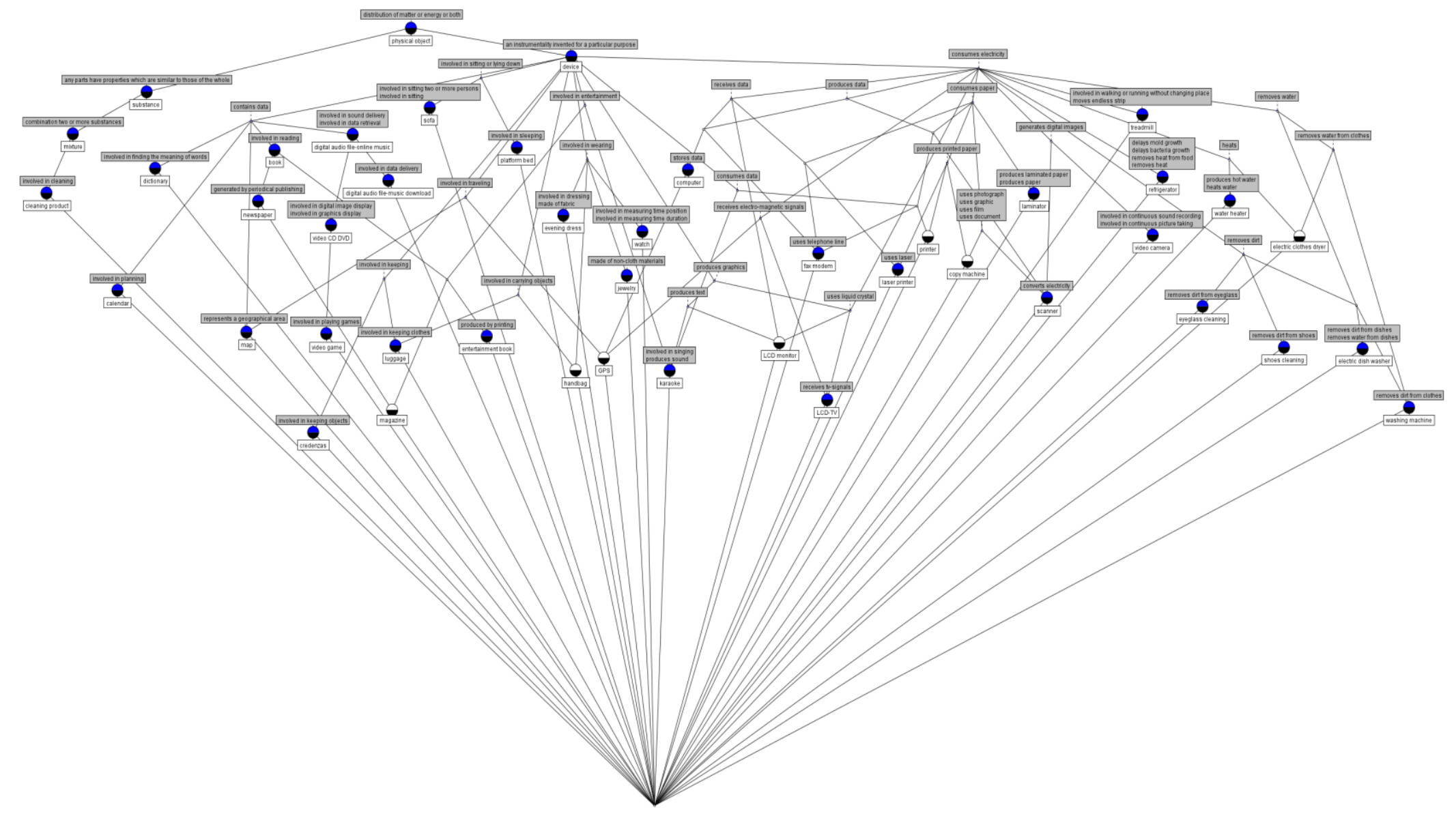




\section{Table 1}

\begin{tabular}{|c|c|c|c|c|c|c|c|c|c|c|c|c|}
\hline Electric kettle with: & $\begin{array}{l}\text { Human } \\
\text { judg- } \\
\text { ment } \\
\text { rank }\end{array}$ & $\begin{array}{l}\text { Wu \& } \\
\text { Palmer }\end{array}$ & $\begin{array}{c}\text { Wu } \\
\text { Palmer } \\
\text { (with } \\
\text { device } \\
\text { class) } \\
\end{array}$ & Lin & Dice & $\begin{array}{c}\text { All } \\
\text { Confi- } \\
\text { dence }\end{array}$ & $\begin{array}{l}\text { Over- } \\
\text { lap }\end{array}$ & $\begin{array}{c}\text { van der } \\
\text { Weken } \\
1\end{array}$ & $\begin{array}{c}\text { van der } \\
\text { Weken } \\
2\end{array}$ & Jaccard & Cosine & Tversky \\
\hline electric dish washer & 0.29 & - & 0.29 & 0.01 & 0.22 & 0.20 & 0.25 & 0.90 & 0.87 & 0.13 & 0.22 & 0.22 \\
\hline washing machine & 0.32 & - & 0.29 & 0.01 & 0.22 & 0.20 & 0.25 & 0.90 & 0.87 & 0.13 & 0.22 & 0.22 \\
\hline electric clothes dryer & 0.62 & 0.40 & 0.57 & 0.18 & 0.50 & 0.50 & 0.50 & 0.93 & 0.93 & 0.33 & 0.50 & 0.50 \\
\hline hair dryer & 0.76 & 0.40 & 0.57 & 0.18 & 0.50 & 0.50 & 0.50 & 0.93 & 0.93 & 0.33 & 0.50 & 0.50 \\
\hline water heater & 1.00 & 1.00 & 1.00 & 1.00 & 1.00 & 1.00 & 1.00 & 1.00 & 1.00 & 1.00 & 1.00 & 1.00 \\
\hline electric blanket & 0.67 & 0.50 & 0.67 & 0.18 & 0.57 & 0.50 & 0.67 & 0.97 & 0.94 & 0.40 & 0.58 & 0.58 \\
\hline toaster & 0.73 & 0.33 & 0.50 & 0.18 & 0.40 & 0.33 & 0.50 & 0.93 & 0.87 & 0.25 & 0.41 & 0.41 \\
\hline bread machine & 0.52 & 0.33 & 0.50 & 0.18 & 0.40 & 0.33 & 0.50 & 0.93 & 0.87 & 0.25 & 0.41 & 0.41 \\
\hline electric oven & 0.80 & 0.33 & 0.50 & 0.18 & 0.33 & 0.25 & 0.50 & 0.92 & 0.80 & 0.20 & 0.35 & 0.35 \\
\hline microwave oven & 0.72 & 0.33 & 0.50 & 0.18 & 0.40 & 0.33 & 0.50 & 0.93 & 0.87 & 0.25 & 0.41 & 0.41 \\
\hline vacuum cleaner & 0.18 & - & 0.33 & 0.01 & 0.25 & 0.25 & 0.25 & 0.90 & 0.90 & 0.14 & 0.25 & 0.25 \\
\hline television set & 0.08 & - & 0.50 & 0.01 & 0.33 & 0.25 & 0.50 & 0.97 & 0.91 & 0.20 & 0.35 & 0.35 \\
\hline room electric heater & 0.81 & 0.50 & 0.67 & 0.20 & 0.57 & 0.50 & 0.67 & 0.97 & 0.94 & 0.40 & 0.58 & 0.58 \\
\hline room air-conditioner & 0.49 & 0.40 & 0.57 & 0.18 & 0.40 & 0.33 & 0.50 & 0.93 & 0.87 & 0.25 & 0.41 & 0.41 \\
\hline conventional electric fan & 0.25 & - & 0.33 & 0.01 & 0.25 & 0.25 & 0.25 & 0.90 & 0.90 & 0.14 & 0.25 & 0.25 \\
\hline refrigerator & 0.34 & - & 0.33 & 0.01 & 0.22 & 0.20 & 0.25 & 0.90 & 0.87 & 0.13 & 0.22 & 0.22 \\
\hline blender & 0.21 & - & 0.33 & 0.01 & 0.25 & 0.25 & 0.25 & 0.90 & 0.90 & 0.14 & 0.25 & 0.25 \\
\hline $\begin{array}{l}\text { Correlation with human } \\
\text { judgment }\end{array}$ & 1.00 & & 0.782 & 0.731 & 0.777 & 0.729 & 0.795 & 0.608 & 0.272 & 0.708 & 0.781 & 0.726 \\
\hline Sum of squared errors & & & 0.474 & 2.713 & 0.688 & 0.941 & 0.484 & 3.921 & 3.532 & 1.576 & 0.662 & 0.930 \\
\hline
\end{tabular}


Table 2

\begin{tabular}{|c|c|c|c|c|c|c|c|c|c|c|c|c|c|}
\hline & Pairs & Scirus & Scholar & $\begin{array}{c}\text { Wu } \\
\text { Palmer }\end{array}$ & Lin & Dice & $\begin{array}{c}\text { All } \\
\text { Confi- } \\
\text { dence }\end{array}$ & Overlap & $\begin{array}{c}\text { van der } \\
\text { Weken } 1\end{array}$ & $\begin{array}{c}\text { van der } \\
\text { Weken } 2\end{array}$ & Jaccard & Cosine & Tversky \\
\hline \multirow{3}{*}{$\stackrel{\frac{5}{5}}{3}$} & counterboring & 1.000 & 1.000 & 1.000 & 1.000 & 1.000 & 1.000 & 1.000 & 1.000 & 1.000 & 1.000 & 1.000 & 1.000 \\
\hline & milling & 0.543 & 0.546 & 0.286 & 0.063 & 0.533 & 0.400 & 0.800 & 0.900 & 0.600 & 0.364 & 0.566 & 0.400 \\
\hline & countersinking & 0.862 & 0.857 & 0.727 & 0.443 & 0.800 & 0.800 & 0.800 & 0.800 & 0.800 & 0.667 & 0.800 & 0.800 \\
\hline \multirow{6}{*}{ 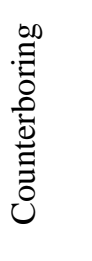 } & drilling & 0.607 & 0.605 & 0.500 & 0.140 & 0.625 & 0.500 & 0.833 & 0.900 & 0.643 & 0.455 & 0.645 & 0.500 \\
\hline & spotfacing & 0.785 & 0.797 & 0.833 & 0.620 & 0.900 & 0.900 & 0.900 & 0.900 & 0.900 & 0.818 & 0.900 & 0.900 \\
\hline & boring & 0.514 & 0.687 & 0.800 & 0.443 & 0.842 & 0.800 & 0.889 & 0.900 & 0.818 & 0.727 & 0.843 & 0.800 \\
\hline & reaming & 0.763 & 0.766 & 0.800 & 0.443 & 0.842 & 0.800 & 0.889 & 0.900 & 0.818 & 0.727 & 0.843 & 0.800 \\
\hline & turning & 0.548 & 0.538 & 0.286 & 0.063 & 0.533 & 0.400 & 0.800 & 0.900 & 0.600 & 0.364 & 0.566 & 0.400 \\
\hline & tapping & 0.695 & 0.703 & 0.800 & 0.203 & 0.842 & 0.800 & 0.889 & 0.900 & 0.818 & 0.727 & 0.843 & 0.800 \\
\hline \multirow{5}{*}{$\frac{5}{3}$} & milling & 1.000 & 0.999 & 1.000 & 1.000 & 1.000 & 1.000 & 1.000 & 1.000 & 1.000 & 1.000 & 1.000 & 1.000 \\
\hline & countersinking & 0.581 & 0.566 & 0.286 & 0.063 & 0.533 & 0.400 & 0.800 & 0.900 & 0.600 & 0.364 & 0.566 & 0.400 \\
\hline & drilling & 0.836 & 0.798 & 0.400 & 0.063 & 0.727 & 0.667 & 0.800 & 0.929 & 0.867 & 0.571 & 0.730 & 0.667 \\
\hline & spotfacing & 0.515 & 0.526 & 0.250 & 0.063 & 0.533 & 0.400 & 0.800 & 0.900 & 0.600 & 0.364 & 0.566 & 0.400 \\
\hline & boring & 0.686 & 0.729 & 0.286 & 0.063 & 0.571 & 0.444 & 0.800 & 0.909 & 0.667 & 0.400 & 0.596 & 0.444 \\
\hline \multirow{3}{*}{$\stackrel{\infty}{\Xi}$} & reaming & 0.674 & 0.657 & 0.286 & 0.063 & 0.571 & 0.444 & 0.800 & 0.909 & 0.667 & 0.400 & 0.596 & 0.444 \\
\hline & turning & 0.883 & 0.805 & 0.500 & 0.063 & 0.800 & 0.800 & 0.800 & 0.933 & 0.933 & 0.667 & 0.800 & 0.800 \\
\hline & tapping & 0.706 & 0.669 & 0.286 & 0.063 & 0.571 & 0.444 & 0.800 & 0.909 & 0.667 & 0.400 & 0.596 & 0.444 \\
\hline \multirow{7}{*}{ 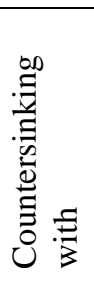 } & countersinking & 1.000 & 1.000 & 1.000 & 1.000 & 1.000 & 1.000 & 1.000 & 1.000 & 1.000 & 1.000 & 1.000 & 1.000 \\
\hline & drilling & 0.636 & 0.628 & 0.500 & 0.140 & 0.625 & 0.500 & 0.833 & 0.900 & 0.643 & 0.455 & 0.646 & 0.500 \\
\hline & spotfacing & 0.771 & 0.798 & 0.727 & 0.443 & 0.800 & 0.800 & 0.800 & 0.800 & 0.800 & 0.667 & 0.800 & 0.800 \\
\hline & boring & 0.509 & 0.674 & 0.600 & 0.203 & 0.737 & 0.700 & 0.778 & 0.800 & 0.727 & 0.583 & 0.738 & 0.700 \\
\hline & reaming & 0.789 & 0.775 & 0.600 & 0.203 & 0.737 & 0.700 & 0.778 & 0.800 & 0.727 & 0.583 & 0.738 & 0.700 \\
\hline & turning & 0.567 & 0.542 & 0.286 & 0.063 & 0.533 & 0.400 & 0.800 & 0.900 & 0.600 & 0.364 & 0.566 & 0.400 \\
\hline & tapping & 0.709 & 0.712 & 0.600 & 0.203 & 0.737 & 0.700 & 0.778 & 0.800 & 0.727 & 0.583 & 0.738 & 0.700 \\
\hline \multirow{6}{*}{ 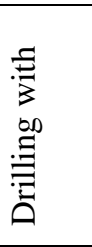 } & drilling & 1.000 & 0.988 & 1.000 & 1.000 & 1.000 & 1.000 & 1.000 & 1.000 & 1.000 & 1.000 & 1.000 & 1.000 \\
\hline & spotfacing & 0.566 & 0.573 & 0.400 & 0.140 & 0.625 & 0.500 & 0.8333 & 0.900 & 0.643 & 0.455 & 0.645 & 0.500 \\
\hline & boring & 0.697 & 0.773 & 0.500 & 0.140 & 0.667 & 0.556 & 0.833 & 0.909 & 0.714 & 0.500 & 0.680 & 0.556 \\
\hline & reaming & 0.729 & 0.723 & 0.500 & 0.140 & 0.667 & 0.556 & 0.833 & 0.909 & 0.714 & 0.500 & 0.680 & 0.556 \\
\hline & turning & 0.808 & 0.767 & 0.400 & 0.063 & 0.727 & 0.667 & 0.800 & 0.929 & 0.867 & 0.571 & 0.730 & 0.667 \\
\hline & tapping & 0.762 & 0.736 & 0.500 & 0.140 & 0.667 & 0.556 & 0.833 & 0.909 & 0.714 & 0.500 & 0.680 & 0.556 \\
\hline \multirow{5}{*}{ 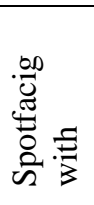 } & spotfacing & 1.000 & 1.000 & 1.000 & 1.000 & 1.000 & 1.000 & 1.000 & 1.000 & 1.000 & 1.000 & 1.000 & 1.000 \\
\hline & boring & 0.474 & 0.546 & 0.545 & 0.203 & 0.737 & 0.700 & 0.778 & 0.800 & 0.727 & 0.583 & 0.738 & 0.700 \\
\hline & reaming & 0.694 & 0.635 & 0.545 & 0.203 & 0.737 & 0.700 & 0.778 & 0.800 & 0.727 & 0.583 & 0.738 & 0.700 \\
\hline & turning & 0.502 & 0.413 & 0.286 & 0.063 & 0.533 & 0.400 & 0.800 & 0.900 & 0.600 & 0.364 & 0.566 & 0.400 \\
\hline & tapping & 0.638 & 0.581 & 0.545 & 0.203 & 0.737 & 0.700 & 0.778 & 0.800 & 0.727 & 0.583 & 0.738 & 0.700 \\
\hline \multirow{2}{*}{$\stackrel{\ominus}{\infty} \Xi$} & boring & 1.000 & 1.000 & 1.000 & 1.000 & 1.000 & 1.000 & 1.000 & 1.000 & 1.000 & 1.000 & 1.000 & 1.000 \\
\hline & reaming & 0.601 & 0.794 & 0.800 & 0.443 & 0.889 & 0.889 & 0.889 & 0.909 & 0.909 & 0.800 & 0.889 & 0.889 \\
\hline
\end{tabular}




\begin{tabular}{|c|c|c|c|c|c|c|c|c|c|c|c|c|c|}
\hline & turning & 0.669 & 0.723 & 0.250 & 0.063 & 0.571 & 0.444 & 0.800 & 0.909 & 0.667 & 0.400 & 0.596 & 0.444 \\
\hline & tapping & 0.602 & 0.783 & 0.800 & 0.443 & 0.889 & 0.889 & 0.889 & 0.909 & 0.909 & 0.800 & 0.889 & 0.889 \\
\hline \multirow{3}{*}{ 兽 } & reaming & 1.000 & 1.000 & 1.000 & 1.000 & 1.000 & 1.000 & 1.000 & 1.000 & 1.000 & 1.000 & 1.000 & 1.000 \\
\hline & turning & 0.661 & 0.639 & 0.286 & 0.063 & 0.571 & 0.444 & 0.800 & 0.909 & 0.667 & 0.400 & 0.596 & 0.444 \\
\hline & tapping & 0.805 & 0.805 & 0.800 & 0.443 & 0.889 & 0.889 & 0.889 & 0.909 & 0.909 & 0.800 & 0.889 & 0.889 \\
\hline \multirow{2}{*}{ 兽 } & & 1.000 & 0.998 & 1.000 & 1.000 & 1.000 & 1.000 & 1.000 & 1.000 & 1.000 & 1.000 & 1.000 & 1.000 \\
\hline & tapping & 0.707 & 0.667 & 0.286 & 0.063 & 0.571 & 0.444 & 0.800 & 0.909 & 0.667 & 0.400 & 0.596 & 0.444 \\
\hline \multirow{7}{*}{ 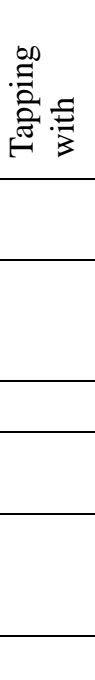 } & tapping & 1.000 & 1.000 & 1.000 & 1.000 & 1.000 & 1.000 & 1.000 & 1.000 & 1.000 & 1.000 & 1.000 & 1.000 \\
\hline & $\begin{array}{l}\text { Correlation } \\
\text { with Scirus }\end{array}$ & 1 & 0.983 & 0.711 & 0.786 & 0.764 & 0.743 & 0.747 & 0.628 & 0.828 & 0.787 & 0.770 & 0.743 \\
\hline & $\begin{array}{l}\text { Sum of } \\
\text { squared errors } \\
\text { (Scirus) }\end{array}$ & & & 2.409 & 9.249 & 0.588 & 1.04 & 1.269 & 2.133 & 0.499 & 1.352 & 0.562 & 1.040 \\
\hline & $2 \sigma \quad$ (Scirus) & & & 0.125 & 0.352 & 0.050 & 0.051 & 0.069 & 0.098 & 0.051 & 0.058 & 0.050 & 0.051 \\
\hline & $\begin{array}{l}\text { Correlation } \\
\text { with Scholar }\end{array}$ & 0.983 & 1 & 0.835 & 0.865 & 0.877 & 0.858 & 0.822 & 0.614 & 0.916 & 0.891 & 0.882 & 0.858 \\
\hline & $\begin{array}{l}\text { Sum of } \\
\text { squared errors } \\
\text { (Scholar) }\end{array}$ & & & 2.058 & 9.259 & 0.291 & 0.727 & 1.019 & 1.923 & 0.256 & 1.124 & 0.272 & 0.727 \\
\hline & $2 \sigma \quad$ (Scholar) & & & 0.122 & 0.317 & 0.17 & 0.040 & 0.061 & 0.102 & 0.017 & 0.059 & 0.017 & 0.040 \\
\hline
\end{tabular}


Table 3

\begin{tabular}{|c|c|c|c|c|c|c|}
\hline \multirow{3}{*}{ Problem } & \multicolumn{2}{|c|}{ Case (product and known solution) } & \multicolumn{4}{|c|}{ Best five matches } \\
\hline & \multirow[t]{2}{*}{ Product } & \multirow[t]{2}{*}{ Service } & \multicolumn{2}{|c|}{$\begin{array}{c}\text { Experiment } 1 \\
\text { (numeric features only) }\end{array}$} & \multicolumn{2}{|c|}{$\begin{array}{c}\text { Experiment } 2 \\
\text { (class feature replaces weight and } \\
\text { volume features) }\end{array}$} \\
\hline & & & Product-service & Similarity & Product-service & Similarity \\
\hline \multirow[t]{5}{*}{1} & \multirow[t]{5}{*}{ Washing machine } & \multirow[t]{5}{*}{ repair } & refrigerator repair & 94 & refrigerator repair & 90 \\
\hline & & & computer repair & 91.29 & computer repair & 89.82 \\
\hline & & & water heater repair & 89.92 & water heater repair & 88.45 \\
\hline & & & laser printer repair & 89.85 & laser printer repair & 87.88 \\
\hline & & & LCD monitor repair & 88.11 & LCD monitor repair & 87.27 \\
\hline \multirow[t]{5}{*}{2} & \multirow[t]{5}{*}{ Refrigerator } & \multirow[t]{5}{*}{ repair } & water heater repair & 95.92 & water heater repair & 94.45 \\
\hline & & & washing machine repair & 94 & computer repair & 91.56 \\
\hline & & & computer repair & 93.02 & LCD monitor repair & 90.43 \\
\hline & & & LCD monitor repair & 91.26 & washing machine repair & 90 \\
\hline & & & laser printer repair & 83.85 & digital calendar & 82.12 \\
\hline \multirow[t]{5}{*}{3} & \multirow[t]{5}{*}{ Computer } & \multirow[t]{5}{*}{ repair } & LCD monitor repair & 95.394 & LCD monitor repair & 94.19 \\
\hline & & & refrigerator repair & 93.02 & refrigerator repair & 91.56 \\
\hline & & & water heater repair & 93.01 & washing machine repair & 89.82 \\
\hline & & & washing machine repair & 91.29 & water heater repair & 89.51 \\
\hline & & & laser printer repair & 85.21 & digital calendar & 84.97 \\
\hline \multirow[t]{5}{*}{4} & \multirow[t]{5}{*}{ Laser printer } & \multirow[t]{5}{*}{ repair } & washing machine repair & 89.85 & washing machine repair & 87.88 \\
\hline & & & printing service & 88.4 & printing service & 87.23 \\
\hline & & & computer repair & 85.21 & computer repair & 82.87 \\
\hline & & & refrigerator repair & 83.85 & refrigerator repair & 81.88 \\
\hline & & & water heater repair & 83.83 & online karaoke & 80.63 \\
\hline \multirow[t]{5}{*}{5} & \multirow[t]{5}{*}{ LCD monitor } & \multirow[t]{5}{*}{ repair } & computer repair & 95.39 & computer repair & 94.19 \\
\hline & & & water heater repair & 95.34 & water heater repair & 92.98 \\
\hline & & & refrigerator repair & 91.26 & refrigerator repair & 90.43 \\
\hline & & & washing machine repair & 88.11 & washing machine repair & 87.27 \\
\hline & & & digital calendar & 86.16 & digital calendar & 85.59 \\
\hline \multirow[t]{5}{*}{6} & \multirow[t]{5}{*}{ Water heater } & \multirow[t]{5}{*}{ repair } & refrigerator repair & 95.92 & refrigerator repair & 94.45 \\
\hline & & & LCD monitor repair & 95.34 & LCD monitor repair & 92.98 \\
\hline & & & computer repair & 93.01 & computer repair & 89.51 \\
\hline & & & washing machine repair & 89.92 & washing machine repair & 88.45 \\
\hline & & & laser printer repair & 83.83 & digital calendar & 84.17 \\
\hline \multirow[t]{5}{*}{7} & \multirow[t]{5}{*}{ Handbag } & repair & jewelry repair & 95 & jewelry repair & 94.15 \\
\hline & & & watch repair & 93.18 & watch repair & 92.33 \\
\hline & & & audio book & 78.20 & treadmill lease & 78.39 \\
\hline & & & LCD TV lease & 77.63 & LCD TV lease & 77.3 \\
\hline & & & treadmill lease & 77.59 & handbag rental & 76.57 \\
\hline
\end{tabular}


Table 3

Cont.

\begin{tabular}{|c|c|c|c|c|c|c|}
\hline \multirow[t]{5}{*}{8} & \multirow[t]{5}{*}{ Jewelry } & \multirow[t]{5}{*}{ repair } & handbag repair & 95 & handbag repair & 94.15 \\
\hline & & & watch repair & 94.08 & watch repair & 92.33 \\
\hline & & & jewelry rental & 80.67 & jewelry rental & 80.67 \\
\hline & & & handbag rental & 79.77 & handbag rental & 78.92 \\
\hline & & & download audio book & 75.00 & treadmill lease & 74.29 \\
\hline \multirow[t]{5}{*}{9} & \multirow[t]{5}{*}{ Watch } & \multirow[t]{5}{*}{ repair } & jewelry repair & 94.08 & jewelry repair & 92.33 \\
\hline & & & handbag repair & 93.18 & handbag repair & 92.33 \\
\hline & & & refrigerator lease & 75.09 & refrigerator lease & 76.99 \\
\hline & & & jewelry rental & 74.75 & sofa lease & 75.86 \\
\hline & & & handbag rental & 73.85 & platform bed lease & 74.25 \\
\hline \multirow[t]{5}{*}{10} & \multirow[t]{5}{*}{ Treadmill } & \multirow[t]{5}{*}{ Lease } & washing machine lease & 94.85 & washing machine lease & 92.95 \\
\hline & & & LCD TV lease & 90.04 & LCD TV lease & 88.37 \\
\hline & & & dryer lease & 89.68 & dryer lease & 87.78 \\
\hline & & & dish washer lease & 82.06 & dish washer lease & 79.26 \\
\hline & & & refrigerator lease & 81.12 & refrigerator lease & 79.22 \\
\hline \multirow[t]{5}{*}{11} & \multirow[t]{5}{*}{ Washing machine } & \multirow[t]{5}{*}{ lease } & treadmill lease & 94.85 & dryer lease & 93.67 \\
\hline & & & dryer lease & 94.83 & treadmill lease & 92.95 \\
\hline & & & LCD TV lease & 93.39 & LCD TV lease & 91.42 \\
\hline & & & refrigerator lease & 86.27 & dish washer lease & 84.31 \\
\hline & & & dish washer lease & 85.41 & refrigerator lease & 82.27 \\
\hline \multirow[t]{5}{*}{12} & \multirow[t]{5}{*}{ LCD TV } & \multirow[t]{5}{*}{ lease } & washing machine lease & 93.39 & washing machine lease & 91.42 \\
\hline & & & treadmill lease & 90.04 & treadmill lease & 88.37 \\
\hline & & & refrigerator lease & 88.81 & refrigerator lease & 86.84 \\
\hline & & & dish washer lease & 88.33 & dryer lease & 86.76 \\
\hline & & & dryer lease & 88.22 & dish washer lease & 85.46 \\
\hline \multirow[t]{5}{*}{13} & \multirow[t]{5}{*}{ Sofa } & \multirow[t]{5}{*}{ lease } & platform bed lease & 91.8 & platform bed lease & 90.05 \\
\hline & & & credenzas lease & 85.29 & credenzas lease & 82.69 \\
\hline & & & refrigerator lease & 85.20 & refrigerator lease & 81.89 \\
\hline & & & treadmill lease & 79.075 & download audio book & 77.43 \\
\hline & & & dish washer lease & 78.02 & treadmill lease & 76.68 \\
\hline \multirow[t]{5}{*}{14} & \multirow[t]{5}{*}{ Dryer } & \multirow[t]{5}{*}{ lease } & washing machine lease & 94.83 & washing machine lease & 93.67 \\
\hline & & & treadmill lease & 89.68 & treadmill lease & 87.78 \\
\hline & & & LCD TV lease & 88.22 & LCD TV lease & 86.76 \\
\hline & & & dish washer lease & 82.84 & dish washer lease & 81.41 \\
\hline & & & refrigerator lease & 81.1 & refrigerator lease & 77.6 \\
\hline \multirow[t]{5}{*}{15} & \multirow[t]{5}{*}{ Platform bed } & \multirow[t]{5}{*}{ lease } & credenzas lease & 93.49 & credenzas lease & 90.89 \\
\hline & & & sofa lease & 91.8 & sofa lease & 90.05 \\
\hline & & & dish washer lease & 86.22 & dish washer lease & 84.52 \\
\hline & & & refrigerator lease & 82.89 & music download & 84.33 \\
\hline & & & music download & 80.83 & download audio book & 83.03 \\
\hline
\end{tabular}


Table 3

Cont.

\begin{tabular}{|c|c|c|c|c|c|c|}
\hline \multirow[t]{5}{*}{16} & \multirow[t]{5}{*}{ Refrigerator } & \multirow[t]{5}{*}{ lease } & LCD TV lease & 88.81 & LCD TV lease & 86.84 \\
\hline & & & washing machine lease & 86.27 & washing machine lease & 82.27 \\
\hline & & & sofa lease & 85.19 & sofa lease & 81.89 \\
\hline & & & platform bed lease & 82.89 & platform bed lease & 80.29 \\
\hline & & & credenzas lease & 82.45 & treadmill lease & 79.22 \\
\hline \multirow[t]{5}{*}{17} & \multirow[t]{5}{*}{ Credenzas } & \multirow[t]{5}{*}{ lease } & platform bed lease & 93.67 & platform bed lease & 90.89 \\
\hline & & & sofa lease & 85.42 & music download & 82.83 \\
\hline & & & refrigerator lease & 82.42 & sofa lease & 82.69 \\
\hline & & & dish washer lease & 81.5 & download audio book & 81.53 \\
\hline & & & music download & 80.83 & refrigerator lease & 78.95 \\
\hline \multirow[t]{5}{*}{18} & \multirow[t]{5}{*}{ Dish washer } & \multirow[t]{5}{*}{ lease } & LCD TV lease & 88.33 & LCD TV lease & 85.46 \\
\hline & & & platform bed lease & 86.22 & platform bed lease & 84.52 \\
\hline & & & washing machine lease & 85.41 & washing machine lease & 84.31 \\
\hline & & & dryer lease & 82.84 & dryer lease & 81.41 \\
\hline & & & treadmill lease & 82.06 & treadmill lease & 79.26 \\
\hline \multirow[t]{5}{*}{19} & \multirow[t]{5}{*}{ Luggage box } & \multirow[t]{5}{*}{ rental } & GPS rental & 94.85 & GPS rental & 91.55 \\
\hline & & & scanning service & 87.5 & scanning service & 84.2 \\
\hline & & & cleaning service & 84.95 & cleaning service & 80.83 \\
\hline & & & video camera rental & 83.67 & eyeglass cleaning service & 79.95 \\
\hline & & & eyeglass cleaning service & 83.25 & video camera rental & 79.47 \\
\hline \multirow[t]{5}{*}{20} & \multirow[t]{5}{*}{ Video CD/DVD } & \multirow[t]{5}{*}{ rental } & entertainment book rental & 94.71 & multimedia on demand & 92.27 \\
\hline & & & fax service & 92.63 & entertainment book rental & 91.21 \\
\hline & & & multimedia on demand & 92.27 & fax service & 90.8 \\
\hline & & & online magazine & 90.84 & online music & 88.4 \\
\hline & & & online music & 88.4 & online magazine & 87.34 \\
\hline \multirow[t]{5}{*}{21} & \multirow[t]{5}{*}{ Evening dress } & \multirow[t]{5}{*}{ rental } & handbag rental & 85.38 & handbag rental & 85.66 \\
\hline & & & jewelry rental & 84.48 & jewelry rental & 85.66 \\
\hline & & & video game rental & 73.73 & video game rental & 72.47 \\
\hline & & & photographer service & 70.28 & handbag repair & 66.33 \\
\hline & & & video camera rental & 70.28 & jewelry repair & 66.33 \\
\hline \multirow[t]{5}{*}{22} & \multirow{5}{*}{$\begin{array}{l}\text { Entertainment } \\
\text { book }\end{array}$} & \multirow[t]{5}{*}{ rental } & video CD/DVD rental & 94.71 & video CD/DVD rental & 91.21 \\
\hline & & & scanning service & 90.29 & scanning service & 87.66 \\
\hline & & & online magazine & 88.4 & online magazine & 87.23 \\
\hline & & & fax service & 87.34 & fax service & 85.84 \\
\hline & & & multimedia on demand & 86.98 & eyeglass cleaning service & 83.88 \\
\hline \multirow[t]{5}{*}{23} & \multirow[t]{5}{*}{ Video game } & \multirow[t]{5}{*}{ rental } & entertainment book rental & 78.18 & video CD/DVD rental & 75.73 \\
\hline & & & jewelry rental & 76.00 & entertainment book rental & 74.68 \\
\hline & & & video CD/DVD rental & 75.73 & handbag rental & 72.50 \\
\hline & & & handbag rental & 75.10 & jewelry rental & 72.50 \\
\hline & & & audio book & 73.77 & evening dress rental & 72.47 \\
\hline
\end{tabular}


Table 3

Cont.

\begin{tabular}{|c|c|c|c|c|c|c|}
\hline \multirow[t]{5}{*}{24} & \multirow[t]{5}{*}{ Jewelry } & \multirow[t]{5}{*}{ rental } & handbag rental & 99.1 & handbag rental & 98.25 \\
\hline & & & evening dress rental & 84.48 & evening dress rental & 85.66 \\
\hline & & & jewelry repair & 80.67 & jewelry repair & 80.67 \\
\hline & & & video game rental & 76.00 & handbag repair & 74.82 \\
\hline & & & handbag repair & 75.67 & watch repair & 73 \\
\hline \multirow[t]{5}{*}{25} & \multirow[t]{5}{*}{ Handbag } & \multirow[t]{5}{*}{ rental } & jewelry rental & 99.1 & jewelry rental & 98.25 \\
\hline & & & evening dress rental & 85.38 & evening dress rental & 85.66 \\
\hline & & & jewelry repair & 79.77 & jewelry repair & 78.92 \\
\hline & & & handbag repair & 76.57 & handbag repair & 76.57 \\
\hline & & & video game rental & 75.10 & watch repair & 73 \\
\hline \multirow[t]{5}{*}{26} & \multirow[t]{5}{*}{ GPS } & \multirow[t]{5}{*}{ rental } & luggage rental & 94.85 & luggage rental & 91.55 \\
\hline & & & eyeglass cleaning service & 88.4 & eyeglass cleaning service & 85.6 \\
\hline & & & cleaning service & 88.3 & cleaning service & 85.08 \\
\hline & & & video camera rental & 87.02 & video camera rental & 84.42 \\
\hline & & & laminating service & 84.15 & laminating service & 80.65 \\
\hline \multirow[t]{5}{*}{27} & \multirow{5}{*}{$\begin{array}{l}\text { DV(video cam- } \\
\text { era) }\end{array}$} & \multirow[t]{5}{*}{ rental } & photographer service & 95.9 & photographer service & 95.9 \\
\hline & & & cleaning service & 88.72 & eyeglass cleaning service & 85.12 \\
\hline & & & eyeglass cleaning service & 87.02 & cleaning service & 84.6 \\
\hline & & & GPS rental & 87.02 & GPS rental & 84.42 \\
\hline & & & luggage rental & 83.67 & laundry service & 82.6 \\
\hline \multirow[t]{5}{*}{28} & \multirow[t]{5}{*}{ Fax modem } & \multirow{5}{*}{$\begin{array}{c}\text { pay per service } \\
\text { unit }\end{array}$} & scanning service & 92.95 & scanning service & 92.08 \\
\hline & & & video $\mathrm{CD} / \mathrm{DVD}$ rental & 92.63 & video $\mathrm{CD} / \mathrm{DVD}$ rental & 90.8 \\
\hline & & & online dictionary & 89.1 & online dictionary & 88.77 \\
\hline & & & laundry service & 88.72 & laundry service & 87.65 \\
\hline & & & eyeglass cleaning service & 88.7 & eyeglass cleaning service & 87.03 \\
\hline \multirow[t]{5}{*}{29} & \multirow[t]{5}{*}{ Printer } & \multirow{5}{*}{$\begin{array}{c}\text { pay per service } \\
\text { unit }\end{array}$} & laundry service & 93.72 & copying service & 92.53 \\
\hline & & & laminating service & 92.05 & laundry service & 92.25 \\
\hline & & & copying service & 91.67 & laminating service & 91.75 \\
\hline & & & laser printer repair & 88.4 & laser printer repair & 87.23 \\
\hline & & & cleaning service & 87.9 & eyeglass cleaning service & 87.03 \\
\hline \multirow[t]{5}{*}{30} & \multirow[t]{5}{*}{ Photostat } & \multirow{5}{*}{$\begin{array}{c}\text { pay per service } \\
\text { unit }\end{array}$} & laundry service & 97.95 & laundry service & 93.95 \\
\hline & & & printing service & 91.67 & printing service & 92.53 \\
\hline & & & cleaning service & 88.07 & eyeglass cleaning service & 89.23 \\
\hline & & & eyeglass cleaning service & 87.97 & scanning service & 87.01 \\
\hline & & & shoes cleaning service & 87.26 & fax service & 86.6 \\
\hline \multirow[t]{5}{*}{31} & \multirow[t]{5}{*}{ Scanning } & \multirow{5}{*}{$\begin{array}{c}\text { pay per service } \\
\text { unit }\end{array}$} & eyeglass cleaning service & 95.75 & eyeglass cleaning service & 92.95 \\
\hline & & & fax service & 92.95 & fax service & 92.08 \\
\hline & & & laminating service & 91.5 & laminating service & 89.17 \\
\hline & & & entertainment book rental & 90.29 & entertainment book rental & 87.66 \\
\hline & & & video $\mathrm{CD} / \mathrm{DVD}$ rental & 87.85 & copying service & 87.01 \\
\hline
\end{tabular}


Table 3

Cont.

\begin{tabular}{|c|c|c|c|c|c|c|}
\hline \multirow[t]{5}{*}{32} & \multirow[t]{5}{*}{ Laminating } & \multirow{5}{*}{$\begin{array}{c}\text { pay per service } \\
\text { unit }\end{array}$} & eyeglass cleaning service & 95.75 & eyeglass cleaning service & 92.95 \\
\hline & & & printing service & 92.05 & printing service & 91.75 \\
\hline & & & scanning service & 91.5 & scanning service & 89.17 \\
\hline & & & laundry service & 85.77 & laundry service & 86.33 \\
\hline & & & fax service & 84.45 & copying service & 85.45 \\
\hline \multirow[t]{5}{*}{33} & \multirow[t]{5}{*}{ Washing machine } & \multirow{5}{*}{$\begin{array}{c}\text { pay per service } \\
\text { unit }\end{array}$} & copying service & 97.95 & copying service & 93.95 \\
\hline & & & printing service & 93.72 & eyeglass cleaning service & 92.68 \\
\hline & & & cleaning service & 90.12 & printing service & 92.25 \\
\hline & & & eyeglass cleaning service & 90.02 & fax service & 87.65 \\
\hline & & & fax service & 88.72 & cleaning service & 86.9 \\
\hline \multirow[t]{5}{*}{34} & \multirow[t]{5}{*}{ Cleaning product } & \multirow{5}{*}{$\begin{array}{c}\text { pay per service } \\
\text { unit }\end{array}$} & laundry service & 90.12 & laundry service & 86.9 \\
\hline & & & video camera rental & 88.72 & eyeglass cleaning service & 85.08 \\
\hline & & & eyeglass cleaning service & 88.3 & GPS rental & 85.08 \\
\hline & & & GPS rental & 88.3 & copying service & 84.85 \\
\hline & & & copying service & 88.07 & video camera rental & 84.6 \\
\hline \multirow[t]{5}{*}{35} & \multirow[t]{5}{*}{ Shoes cleaning } & \multirow{5}{*}{$\begin{array}{c}\text { pay per service } \\
\text { unit }\end{array}$} & copying service & 87.26 & eyeglass cleaning service & 91.53 \\
\hline & & & laundry service & 85.21 & copying service & 90.36 \\
\hline & & & eyeglass cleaning service & 82.96 & laundry service & 89.71 \\
\hline & & & printing service & 78.925 & laminating service & 85.88 \\
\hline & & & laminating service & 78.71 & scanning service & 85.88 \\
\hline \multirow[t]{5}{*}{36} & \multirow[t]{5}{*}{ Eyeglass cleaning } & \multirow{5}{*}{$\begin{array}{c}\text { pay per service } \\
\text { unit }\end{array}$} & laminating service & 95.75 & laminating service & 92.95 \\
\hline & & & scanning service & 95.75 & scanning service & 92.95 \\
\hline & & & laundry service & 90.02 & laundry service & 92.68 \\
\hline & & & fax service & 88.7 & copying service & 89.23 \\
\hline & & & GPS rental & 88.4 & printing service & 87.03 \\
\hline \multirow[t]{5}{*}{37} & \multirow{5}{*}{$\begin{array}{l}\text { DV(video cam- } \\
\text { era) }\end{array}$} & \multirow{5}{*}{$\begin{array}{c}\text { pay per service } \\
\text { unit }\end{array}$} & video camera rental & 95.9 & video camera rental & 95.9 \\
\hline & & & cleaning service & 84.62 & eyeglass cleaning service & 81.02 \\
\hline & & & eyeglass cleaning service & 82.92 & copying service & 80.55 \\
\hline & & & GPS rental & 82.92 & cleaning service & 80.5 \\
\hline & & & copying service & 80.88 & GPS rental & 80.32 \\
\hline \multirow[t]{5}{*}{38} & \multirow{5}{*}{$\begin{array}{l}\text { Music CD (online } \\
\text { music) }\end{array}$} & \multirow[t]{5}{*}{ functional result } & online newspaper & 97.16 & multimedia on demand & 96.13 \\
\hline & & & multimedia on demand & 96.13 & online newspaper & 94.36 \\
\hline & & & online magazine & 94.71 & online magazine & 91.91 \\
\hline & & & online dictionary & 91.93 & online dictionary & 90.18 \\
\hline & & & video $\mathrm{CD} / \mathrm{DVD}$ rental & 88.4 & video $\mathrm{CD} / \mathrm{DVD}$ rental & 88.4 \\
\hline \multirow[t]{5}{*}{39} & \multirow[t]{5}{*}{ Magazine } & \multirow[t]{5}{*}{ functional result } & multimedia on demand & 98.58 & multimedia on demand & 95.08 \\
\hline & & & online newspaper & 94.71 & online newspaper & 94.71 \\
\hline & & & online music & 94.71 & online dictionary & 92.63 \\
\hline & & & online dictionary & 94.38 & online music & 91.91 \\
\hline & & & video CD/DVD rental & 90.84 & online karaoke & 88.78 \\
\hline
\end{tabular}


Table 3

\begin{tabular}{|c|c|c|c|c|c|c|}
\hline \multirow[t]{5}{*}{40} & \multirow{5}{*}{ Karaoke } & \multirow{5}{*}{ functional result } & multimedia on demand & 91.67 & online magazine & 88.78 \\
\hline & & & online magazine & 90.24 & multimedia on demand & 88.7 \\
\hline & & & online music & 87.8 & online dictionary & 86 \\
\hline & & & online dictionary & 87.47 & online music & 85.63 \\
\hline & & & online newspaper & 84.96 & online newspaper & 82.79 \\
\hline \multirow[t]{5}{*}{41} & \multirow{5}{*}{$\begin{array}{l}\text { Music CD (music } \\
\text { download) }\end{array}$} & \multirow[t]{5}{*}{ functional result } & download audio book & 98.7 & download audio book & 96.95 \\
\hline & & & platform bed lease & 80.83 & platform bed lease & 84.33 \\
\hline & & & credenzas lease & 80.23 & credenzas lease & 82.83 \\
\hline & & & dish washer lease & 78.38 & dish washer lease & 78.92 \\
\hline & & & online music & 78.03 & online music & 78.03 \\
\hline \multirow[t]{5}{*}{42} & \multirow{5}{*}{$\begin{array}{l}\text { Video } \\
\text { CD/DVD(multim } \\
\text { edia on demand) }\end{array}$} & \multirow[t]{5}{*}{ functional result } & online magazine & 98.58 & online music & 96.13 \\
\hline & & & online music & 96.13 & online magazine & 95.08 \\
\hline & & & online dictionary & 95.8 & online dictionary & 94.05 \\
\hline & & & online newspaper & 93.29 & video $\mathrm{CD} / \mathrm{DVD}$ rental & 92.27 \\
\hline & & & video CD/DVD rental & 92.27 & online newspaper & 90.49 \\
\hline \multirow[t]{5}{*}{43} & \multirow[t]{5}{*}{ MAP } & \multirow[t]{5}{*}{ functional result } & online magazine & 85.4 & online magazine & 83.5 \\
\hline & & & online dictionary & 83.98 & online dictionary & 83.13 \\
\hline & & & multimedia on demand & 83.98 & multimedia on demand & 82.08 \\
\hline & & & luggage rental & 80.79 & luggage rental & 78.63 \\
\hline & & & online newspaper & 80.11 & online newspaper & 78.21 \\
\hline \multirow[t]{5}{*}{44} & \multirow[t]{5}{*}{ Newspaper } & \multirow[t]{5}{*}{ functional result } & online music & 97.16 & online magazine & 83.5 \\
\hline & & & online magazine & 94.71 & online dictionary & 83.13 \\
\hline & & & multimedia on demand & 93.29 & multimedia on demand & 82.08 \\
\hline & & & digital calendar & 89.12 & luggage rental & 78.63 \\
\hline & & & online dictionary & 89.09 & online newspaper & 78.21 \\
\hline \multirow[t]{5}{*}{45} & \multirow[t]{5}{*}{ Dictionary } & \multirow[t]{5}{*}{ functional result } & multimedia on demand & 95.8 & multimedia on demand & 94.05 \\
\hline & & & online magazine & 94.38 & online magazine & 92.63 \\
\hline & & & online music & 91.93 & online music & 90.18 \\
\hline & & & fax service & 89.1 & fax service & 88.77 \\
\hline & & & online newspaper & 89.09 & online newspaper & 87.3 \\
\hline \multirow[t]{5}{*}{46} & \multirow[t]{5}{*}{ Calendar } & \multirow[t]{5}{*}{ functional result } & online newspaper & 89.12 & online newspaper & 87.37 \\
\hline & & & online music & 86.27 & LCD monitor repair & 85.59 \\
\hline & & & LCD monitor repair & 86.16 & computer repair & 84.97 \\
\hline & & & online dictionary & 84.51 & online music & 84.52 \\
\hline & & & computer repair & 84.40 & water heater repair & 84.17 \\
\hline \multirow[t]{5}{*}{47} & \multirow[t]{5}{*}{ Book } & \multirow[t]{5}{*}{ functional result } & music download & 98.7 & music download & 96.95 \\
\hline & & & platform bed lease & 79.53 & platform bed lease & 83.03 \\
\hline & & & credenzas lease & 78.93 & credenzas lease & 81.53 \\
\hline & & & handbag repair & 78.20 & dish washer lease & 78.78 \\
\hline & & & dish washer lease & 77.08 & sofa lease & 77.43 \\
\hline
\end{tabular}




\section{Table 4}

\begin{tabular}{|c|c|c|}
\hline \multirow[b]{2}{*}{ Problem } & \multicolumn{2}{|c|}{ Number of best cases that are identical with Experiment 1} \\
\hline & $\begin{array}{c}\text { Experiment } 2 \\
\text { (using a class feature instead of volume } \\
\text { and weight) }\end{array}$ & $\begin{array}{c}\text { Experiment } 3 \\
\text { (only numeric features but volume and weight } \\
\text { are excluded) }\end{array}$ \\
\hline 1 & 5 & 5 \\
\hline 2 & 4 & 5 \\
\hline 3 & 4 & 4 \\
\hline 4 & 4 & 4 \\
\hline 5 & 5 & 5 \\
\hline 6 & 4 & 4 \\
\hline 7 & 4 & 2 \\
\hline 8 & 4 & 4 \\
\hline 9 & 3 & 3 \\
\hline 10 & 5 & 5 \\
\hline 11 & 5 & 5 \\
\hline 12 & 5 & 5 \\
\hline 13 & 4 & 4 \\
\hline 14 & 5 & 5 \\
\hline 15 & 4 & 4 \\
\hline 16 & 4 & 5 \\
\hline 17 & 4 & 4 \\
\hline 18 & 5 & 4 \\
\hline 19 & 5 & 3 \\
\hline 20 & 5 & 4 \\
\hline 21 & 3 & 4 \\
\hline 22 & 4 & 3 \\
\hline 23 & 4 & 3 \\
\hline 24 & 4 & 3 \\
\hline 25 & 4 & 3 \\
\hline 26 & 5 & 3 \\
\hline 27 & 4 & 2 \\
\hline 28 & 5 & 4 \\
\hline 29 & 4 & 4 \\
\hline
\end{tabular}


Table 4

Cont.

\begin{tabular}{|c|c|c|}
\hline \multirow[b]{2}{*}{ Problem } & \multicolumn{2}{|c|}{ Number of best cases that are identical with Experiment 1} \\
\hline & $\begin{array}{c}\text { Experiment } 2 \\
\text { (using a class feature instead of vol- } \\
\text { ume and weight) }\end{array}$ & $\begin{array}{c}\text { Experiment } 3 \\
\text { (only numeric features but volume and } \\
\text { weight are excluded) }\end{array}$ \\
\hline 30 & 3 & 3 \\
\hline 31 & 4 & 5 \\
\hline 32 & 4 & 4 \\
\hline 33 & 5 & 4 \\
\hline 34 & 5 & 1 \\
\hline 35 & 4 & 4 \\
\hline 36 & 3 & 3 \\
\hline 37 & 5 & 2 \\
\hline 38 & 5 & 4 \\
\hline 39 & 4 & 4 \\
\hline 40 & 5 & 5 \\
\hline 41 & 5 & 4 \\
\hline 42 & 5 & 4 \\
\hline 43 & 5 & 1 \\
\hline 44 & 3 & 5 \\
\hline 45 & 5 & 4 \\
\hline 46 & 4 & 4 \\
\hline 47 & 4 & 4 \\
\hline Average & 4.32 & 3.79 \\
\hline
\end{tabular}

